\title{
Effects of nominally
} selective inhibitors of the kinases PI3K, SGK1 and PKB on the insulin-dependent control of epithelial $\mathrm{Na}^{+}$absorption

\section{Correspondence}

Dr Stuart M Wilson, Centre for Cardiovascular and Lung Biology, Division of Medical Sciences, Ninewells Hospital and Medical School, University of Dundee, Dundee DD1 9SY, UK. E-mail: s.m.wilson@dundee.ac.uk

\section{Keywords}

kinase inhibitors; Akti-1/2; GSK650394A; PI103; GDC-0941; epithelial $\mathrm{Na}^{+}$channel; cortical collecting duct

\section{Received}

30 January 2010

Revised

9 April 2010

Accepted

19 April 2010

Morag K Mansley and Stuart M Wilson

Centre for Cardiovascular and Lung Biology, Division of Medical Sciences, College of Medicine, Dentistry and Nursing, University of Dundee, Dundee, UK

\section{BACKGROUND AND PURPOSE}

Insulin-induced $\mathrm{Na}^{+}$retention in the distal nephron may contribute to the development of oedema/hypertension in patients with type 2 diabetes. This response to insulin is usually attributed to phosphatidylinositol-3-kinase (PI3K)/serum and glucocorticoid-inducible kinase 1 (SGK1) but a role for protein kinase B (PKB) has been proposed. The present study therefore aimed to clarify the way in which insulin can evoke $\mathrm{Na}^{+}$retention.

\section{EXPERIMENTAL APPROACH}

We examined the effects of nominally selective inhibitors of PI3K (wortmannin, PI103, GDC-0941), SGK1 (GSK650394A) and PKB (Akti-1/2) on $\mathrm{Na}^{+}$transport in hormone-deprived and insulin-stimulated cortical collecting duct (mpkCCD) cells, while PI3K, SGK1 and PKB activities were assayed by monitoring the phosphorylation of endogenous proteins.

\section{KEY RESULTS}

Wortmannin substantially inhibited basal $\mathrm{Na}^{+}$transport whereas PI103 and GDC-0941 had only very small effects. However, these PI3K inhibitors all abolished insulin-induced $\mathrm{Na}^{+}$absorption and inactivated PI3K, SGK1 and PKB fully. GSK650394A and Akti-1/2 also inhibited insulin-evoked $\mathrm{Na}^{+}$absorption and while GSK650394A inhibited SGK1 without affecting PKB, Akti-1/2 inactivated both kinases.

\section{CONCLUSION AND IMPLICATIONS}

While studies undertaken using PI103 and GDC-0941 show that hormone-deprived cells can absorb $\mathrm{Na}^{+}$independently of PI3K, PI3K seems to be essential for insulin induced $\mathrm{Na}^{+}$transport. Akti-1/2 does not act as a selective inhibitor of PKB and data obtained using this compound must therefore be treated with caution. GSK650394A, on the other hand, selectively inhibits SGK1 and the finding that GSK650394A suppressed insulin-induced $\mathrm{Na}^{+}$absorption suggests that this response is dependent upon signalling via PI3K/SGK1.

\section{Abbreviations}

Akti-1/2, inhibitor of Akt (also known as PKB) 1/2; ANOvA, analysis of variance; CK2, casein kinase 2; CCD, cortical collecting duct; DMSO, dimethyl sulphoxide; DMEM, Dulbecco's modified Eagle's media; EDTA, ethylenediaminetetraacetic acid; EGTA, ethylene glycol-bis(2-aminoethylether)-N,N, $\mathrm{N}^{\prime}, \mathrm{N}^{\prime}$-tetraacetic acid; EIPA, 5-(N-ethyl-N-isopropyl) amiloride; ENaC, epithelial sodium channel; FBS, foetal bovine serum; $G_{\mathrm{Na}}$, membrane $\mathrm{Na}^{+}$ conductance; GILZ1-3, glucocorticoid-inducible leucine zipper proteins 1-3; GLUT4, glucose transporter 4; GSK3, glycogen synthase kinase 3; HIPK, homeodomain-interacting protein kinase; $I_{\mathrm{Eq}}$, equivalent short circuit current; $I_{\mathrm{SC}}$, short circuit current; $\mathrm{IC}_{50}$, concentration needed for 50\% inhibition; Nedd-4/2, neural precursor cell expressed, developmentally down-regulated protein 4-2; NDRG1 and 2, protein encoded by n-myc downstream regulated gene 1 
and gene 2; PDK1, phosphoinositide-dependent protein kinase 1; PH domain, plekstrin homology domain; PI3K, phosphatidylinositol-3-kinase; PIMK, provirus integration site for Moloney murine leukaemia virus kinase; PIP $_{2}$, phosphatidylinostiol 3,5-bisphosphate; $\mathrm{PIP}_{3}$, phosphatidylinositol 3,4,5-trisphosphate; PKB, protein kinase B (also known as Akt); PLK1, polo-like kinase 1; PRAS40, $40 \mathrm{kDa}$ proline-rich substrate of Akt (PKB); P70-S6K, 70 kDa ribosomal S6 kinase; $R_{\mathrm{t}}$, transepithelial resistance; SDS, sodium dodecyl sulphate; SGK1, serum and glucocorticoid-inducible kinase 1; SmMLCK, smooth-muscle myosin light-chain kinase; TORC1 and 2, target of rapamycin complex 1 and 2; $V_{\mathrm{t}}$, transepithelial voltage

\section{Introduction}

The regulated re-absorption of $\mathrm{Na}^{+}$within the aldosterone-sensitive epithelia of the distal nephron (ASDN; late distal convoluted tubule and the cortical collecting duct) is a physiologically important process that determines the amount of $\mathrm{Na}^{+}$lost in urine, and this absorptive mechanism is therefore of central importance to $\mathrm{Na}^{+}$homeostasis, whole body fluid balance and the control of blood pressure (reviewed by Loffing and Korbmacher, 2009). $\mathrm{Na}^{+}$absorption within the ASDN is dependent upon epithelial $\mathrm{Na}^{+}$channels $(\mathrm{ENaC}$ ), transport proteins composed of 3 subunits $(\alpha-, \beta-$ and $\gamma$-ENaC) that form the highly selective $\mathrm{Na}^{+}$ channels, which allow apical $\mathrm{Na}^{+}$entry in absorptive epithelia (Canessa et al., 1993; 1994). The activity and/or surface expression of these channels is controlled by the hormones involved in the control of $\mathrm{Na}^{+}$and water balance (aldosterone and vasopressin) but, in addition to its role in carbohydrate metabolism, insulin is also known to stimulate $\mathrm{Na}^{+}$absorption within the ASDN (Atchley et al., 1936; Defronzo et al., 1975; 1976; Blazer-Yost et al., 1998; Tiwari et al., 2007; Loffing and Korbmacher, 2009). While this effect may normally have little physiological significance (Loffing and Korbmacher, 2009), it can become relevant in patients with type 2 diabetes, as this condition is almost invariably treated using drugs that exert a generalized insulin-sensitizing action. At least some such drugs can cause tissue oedema, high blood pressure and increased risk of congestive heart failure, particularly if co-administered with insulin itself. While the mechanism underlying this oedema is not well understood (see review Buckingham and Hanna, 2007), it does seem to involve inappropriate stimulation of renal $\mathrm{Na}^{+}$ retention (Hong et al., 2003; Guan et al., 2005). Ideally, type 2 diabetes should therefore be treated using drugs that promote glucose uptake without altering renal $\mathrm{Na}^{+}$handling, but this goal will only become achievable once the signalling pathways that allow insulin to control $\mathrm{Na}^{+}$transport are fully understood. The present study therefore explores the mechanisms that allow insulin to stimulate $\mathrm{Na}^{+}$transport in a cell line (mpkCCD) derived from the mouse cortical collecting duct (Bens et al., 1999).

\section{Methods}

\section{Cell culture}

Standard techniques were used to maintain the mpkCCD cell line, which is derived from the mouse cortical collecting duct (Bens et al., 1999), in serial culture. The medium used was phenol red-free DMEM/Ham's F12 supplemented with glutamine $(2 \mathrm{mM})$, foetal bovine serum (FBS, 2\%, v/v), penicillin/streptomycin mixture (1\%; Sigma, Poole, Dorset, UK), sodium selenate $(60 \mathrm{nM})$, transferrin $\left(5 \mu \mathrm{g} \cdot \mathrm{mL}^{-1}\right)$; dexamethasone $(50 \mathrm{nM})$, triiodothyronine $(1 \mathrm{nM})$, epidermal growth factor $\left(10 \mathrm{ng} \cdot \mathrm{mL}^{-1}\right)$ and insulin $\left(5 \mu \mathrm{g} \cdot \mathrm{mL}^{-1}\right)$. For experiments, cells were removed from culture flasks using trypsin/EDTA and plated onto Snapwell membranes $\left(5 \times 10^{5} \mathrm{cells} \cdot \mathrm{cm}^{-2}\right.$, electrometric studies) or Transwell membranes (2.5 $\times 10^{6}$ cells $\cdot \mathrm{cm}^{-2}$, Western analysis). Cells were then cultured in complete medium that was replaced every $48 \mathrm{~h}$, and after 6 days, this standard medium was replaced with hormone-free medium (phenol red-free DMEM/Ham's F12 medium containing antibiotics and $2 \%$ charcoal-stripped FBS). After a further $24 \mathrm{~h}$, serum was withdrawn and the cells used in experiments after a further 18-24 h.

\section{Quantification of $\mathrm{Na}^{+}$transport}

Snapwell membranes bearing confluent cells (see above) were mounted in Ussing chambers and bathed with bicarbonate-buffered physiological salt solution (composition in mM: $\mathrm{NaCl}, 112 ; \mathrm{NaHCO}_{3}$, 25; $\mathrm{KCl}, 4.7 ; \mathrm{MgSO}_{4}, 1.2 ; \mathrm{KH}_{2} \mathrm{PO}_{4}, 1.2 ; \mathrm{CaCl}_{2}, 2.5$ and D-glucose, 11.6, $\mathrm{pH} 7.3-7.5$ when bubbled with $5 \%$ $\mathrm{CO}_{2}$ ). All cells were maintained under open circuit conditions and transepithelial potential difference $\left(V_{\mathrm{t}}\right)$ was monitored (DVC-1000 Voltage/Current Clamp, World Precision Instruments, Stevenage, UK) and recorded $(4 \mathrm{~Hz})$ directly to computer disk (ADI Powerlab Interface and associated software; AD Instruments, Chalgrove, Oxfordshire, UK). Experiments were initiated once $V_{\mathrm{t}}$ had stabilized (40$50 \mathrm{~min}$ ) and, during each recording, standard pulses of transepithelial current $\left(20 \mathrm{~s},-10 \mu \mathrm{A} \cdot \mathrm{cm}^{-2}\right)$ were 
injected every $40 \mathrm{~s}$. The magnitudes of the resultant deflections in $V_{\mathrm{t}}\left(\Delta V_{\mathrm{t}}\right)$ were then used to calculate transepithelial resistance $\left(R_{\mathrm{t}}\right)$ which allowed the equivalent short circuit current ( $I_{\mathrm{Eq}}$; i.e. the current that would be required to hold $V_{\mathrm{t}}$ at $0 \mathrm{mV}$ ) to be calculated using the expression $I_{\mathrm{Eq}}=V_{\mathrm{t}} / R_{\mathrm{t}}$. Such calculations were undertaken using spreadsheet software (Microsoft Excel) and, because all experimental manoeuvres were carefully timed, we were able to align the individual data sets, which allowed us to calculate mean values showing the pooled data for each series of experiments undertaken.

All values of $V_{\mathrm{t}}$ are shown relative to an earth electrode in the basaolateral bath, which implies that the current carried by cations moving from the lumen to the interstitium will be negative. Such currents are therefore shown as downward deflections of the traces. While this convention differs from that used in many previous electrometric studies of cultured epithelia (see e.g. Wilson et al., 2010), it does accord with more general conventions that are invariably used in electrophysiological studies of single cells. Moreover, the experimental approach used in this study differs from that followed in our earlier studies because, until now, we have always measured short circuit current (ISC) directly from cultures held under voltage clamp (see e.g. Wilson et al., 2010). The values of $I_{\mathrm{Eq}}$ reported here are, however, very similar to our recently reported values (Wilson et al., 2010) and it is therefore clear that the two approaches do provide essentially identical data. We believe that the present method is preferable because, even in hormonedeprived cells, $V_{\mathrm{t}}$ is -20 to $-40 \mathrm{mV}$ and this potential can hyperpolarize to $-70 \mathrm{mV}$ during insulin stimulation. Holding $V_{\mathrm{t}}$ at $0 \mathrm{mV}$ in order to measure $I_{\mathrm{SC}}$ directly would therefore hyperpolarize the apical membrane potential and establish electrochemical driving forces for ionic movements that may not occur in vivo. This has the potential to alter the physiological properties of the cells.

\section{Western analysis of extracted protein}

Cells on Transwell membranes were washed with ice-cold phosphate buffered saline and scraped into ice-cold lysis buffer containing protease and phosphatase inhibitors $(1 \%$ Triton; $50 \mathrm{mM}$ Tris $-\mathrm{HCl}$, pH 7.5; 1 mM EGTA; 1 mM EDTA; 1 mM Na orthovanadate; $10 \mathrm{mM}$ glycerol phosphate; $50 \mathrm{mM} \mathrm{NaF}$; $5 \mathrm{mM}$ Na pyrophosphate; $270 \mathrm{mM}$ sucrose; $0.1 \%$ $\beta$-mercaptoethanol; 1 Roche Mini Protease Inhibitor tablet per $10 \mathrm{~mL}$ ). Lysates were then transferred to Eppendorf tubes, ultrasonicated to ensure complete cellular disruption and their protein contents determined using Bradford reagent. Aliquots of extracted protein were then reduced and denatured by heating $\left(95^{\circ} \mathrm{C}, 5 \mathrm{~min}\right)$ in the presence of $5 \%$ $\beta$-mercapto-ethanol and 10\% sodium dodecyl sulphate (SDS) and fractionated on 10\% SDSpolyacrylamide gels. The fractionated proteins were then transferred to Hybond-P membranes (Amersham, Bucks., UK) that were probed using the antibodies described below. Immunoreactive proteins were visualized by enhanced chemiluminesence.

\section{Activity of endogenous kinase activity}

PI3K activation was monitored using Western analysis (see above) to monitor changes in the cellular abundance of $\mathrm{Ser}^{473}$-phosphorylated $\mathrm{PKB}$, as it is now clear that the phosphorylation status of this residue provides a reliable read out of cellular PI3K activity (Bayascas and Alessi, 2005). These analyses were undertaken using antibodies against $\mathrm{Ser}^{473}$. phosphorylated and total PKB. Serum and glucocorticoid-inducible kinase 1 (SGK1) activity was monitored by assaying the phosphorylation status of residues $\left(\mathrm{Thr}^{346 / 356 / 366}\right)$ within NDRG1 that are physiological substrates for SGK1 and not for other, closely related kinases including PKB (Murray et al., 2005a; García-Martínez and Alessi, 2008; Inglis et al., 2009). Similarly, the phosphorylation of PRAS40-Ser ${ }^{246}$ was monitored as an indicator of PKB activity (Kovacina et al., 2003), while P70-S6K-Thr ${ }^{389}$ phosphorylation was assumed to indicate kinase activity of the target of rapamycin signalling complex 1 (TORC1). The results of all such experiments were quantified by densitometry using the Syngene Genegenius image capturing system, GeneSnap image capturing program and GeneTools densitometry analysis program (Synoptics Ltd., Cambridge, UK).

\section{Experimental design and data analysis}

All experiments were undertaken using strictly paired protocols in which control and experimental cells were age-matched and at identical passage. Care was taken to ensure that the control and experimental cells were handled identically and electrometric studies were therefore undertaken using parallel Ussing chamber systems, so that we could simultaneously record currents from control and experimental cells. Analyses of extracted proteins were similarly undertaken using paired experimental designs in which the phosphorylation of endogenous proteins was assayed both in hormonedeprived and insulin-stimulated cells. All experiments involving putative inhibitors of protein kinases involved the analysis of protein extracted from pairs of hormone-deprived/insulin-stimulated cells that had either been exposed to the test compound or to the solvent vehicle (0.1\% DMSO). Initial experiments showed that this concentration 
of DMSO had no effect on any of the parameters studied (not shown). All data are presented as mean \pm SEM, and values of $n$ refer to the number of times a protocol was repeated using cells at different passage. The statistical significance of differences between data derived from hormone-deprived and insulin-stimulated cells were assessed using Student's paired $t$-test, whereas the results of experiments undertaken using more complex protocols were analysed by one- or two-way analysis of variance/Bonferroni post hoc test.

\section{Materials}

Amiloride, 5-(N-Ethyl-N-isopropyl) amiloride (EIPA), benzamil, insulin, culture reagents and all general laboratory reagents were from Sigma (Poole, UK) while PI103, rapamycin and inhibitor of Akt (PKB) 1/2 (Akti-1/2, Barnett et al., 2005; Lindsley et al., 2005) were from Merck (Beeston, UK). GSK650394A and GDC-0941 were a generous gift from Prof D.R. Alessi, who had arranged for these compounds to be synthesized within the MRC Protein Phosphorylation Unit (MRC-PPU) at the University of Dundee. Antibodies against $\mathrm{Ser}^{473}$ phosphorylated and total protein kinase B (PKB), and $\mathrm{Thr}^{389}$-phosphorylated and total $70 \mathrm{kDa}$ ribosomal S6 kinase (P70-S6K) were from Upstate (Watford, UK) while the antibodies against $\mathrm{Thr}^{346 / 356 /}$ 366-phosphorylated and full length forms of the protein encoded by the n-myc downstream regulated gene 1 (NDRG1), and the $\mathrm{Ser}^{246}$. phosphorylated and total forms of the proline-rich $40 \mathrm{kDa}$ substrate of Akt (PKB) (PRAS40) were prepared within the antibody production unit within the MRC-PPU. We are grateful to Prof Sir Phillip Cohen (MRC-PPU) for allowing us access to these antibodies.

\section{Results}

\section{Bioelectric properties of}

hormone-deprived cells

Initial studies of confluent cells $(n=8)$ showed that $V_{\mathrm{t}}, R_{\mathrm{t}}$ and $I_{\mathrm{Eq}}$ were normally $\sim-43.8 \pm 1.5 \mathrm{mV}, \sim 2.5$ $\pm 0.2 \mathrm{k} \Omega \cdot \mathrm{cm}^{2}$ and $\sim-16.2 \pm 1.7 \mu \mathrm{A} \cdot \mathrm{cm}^{-2}$, respectively, and, as anticipated (see Bens et al., 1999), amiloride $(10 \mu \mathrm{M})$ caused a rapid (5-10 s) and almost complete depolarization of $V_{\mathrm{t}}(-3.9 \pm$ $0.4 \mathrm{mV}, P<0.001)$. As this response was accompanied by an increase in $R_{\mathrm{t}}\left(4.4 \pm 0.4 \mathrm{k} \Omega \cdot \mathrm{cm}^{2}, P<\right.$ $0.001)$, this $\mathrm{ENaC}$ blocker essentially abolished $I_{\mathrm{Eq}}$ $\left(-0.8 \pm 0.1 \mu \mathrm{A} \cdot \mathrm{cm}^{-2}, P<0.001\right)$. Further experiments $(n=9)$ in which the apical concentration of amiloride was increased progressively showed that these effects were concentration-dependent and established that concentrations $>10 \mu \mathrm{M}$ were maximally effective. The concentration needed for half maximal inhibition $\left(\mathrm{IC}_{50}\right.$ ) of $I_{\mathrm{Eq}}$ was $0.74 \pm 0.01 \mu \mathrm{M}$. Benzamil reproduced these effects of amiloride fully but was $\sim 35$-fold more potent $\left(\mathrm{EC}_{50}=22.7 \pm 1 \mathrm{nM}\right.$, $n=9)$ and, while EIPA also depolarized $V_{\mathrm{t}}$ and increased $R_{\mathrm{t}}$, the highest concentration tested $(3 \times$ $10^{-4} \mathrm{M}$ ) caused only $\sim 75 \%$ inhibition of $I_{\mathrm{Eq}}$ which made it difficult to estimate IC $_{50}$ accurately. EIPA was, however, $\sim 100$-fold less potent than amiloride $\left(\mathrm{IC}_{50}=90 \pm 20 \mu \mathrm{M}, n=7\right)$. The rank order of potency among these compounds is therefore benzamil > amiloride > EIPA. This observation confirms (see Bens et al., 1999) that hormone-deprived mpkCCD cells spontaneously absorb $\mathrm{Na}^{+}$from the apical bath via an ENaC-dependent mechanism.

\section{Bioelectric response to insulin}

Figure 1 shows the results of experiments that explored the effects of insulin on the bioelectric properties of these cells. $V_{\mathrm{t}}$ was $\sim-50 \mathrm{mV}$ at the onset of these experiments and, because $R_{\mathrm{t}}$ was $\sim 2 \mathrm{k} \Omega \cdot \mathrm{cm}^{2}$, these data confirm (see above) that $I_{\mathrm{Eq}}$ is normally $\sim-20 \mu \mathrm{A} \cdot \mathrm{cm}^{-2}$ (Figure 1). The control data show that $V_{\mathrm{t}}$ tended to depolarize slightly with time and, as $R_{\mathrm{t}}$ was stable, this effect is reflected by a slight decline in $I_{\mathrm{Eq}}$ (Figure 1). Insulin $(20 \mathrm{nM}$, basolateral) hyperpolarized $V_{\mathrm{t}}$ to $\sim-60 \mathrm{mV}$ and this response became apparent after 3-5 min latency and reached a plateau after $\sim 45$ min (Figure 1). This hyperpolarization was accompanied by only a small fall in $R_{\mathrm{t}}$ (Figure 1) and further analysis showed that insulin evoked an augmentation of $I_{\mathrm{Eq}}$ that reached a plateau after $\sim 30 \mathrm{~min}$ (Figure 1). Apical amiloride $(10 \mu \mathrm{M})$ abolished $V_{\mathrm{t}}$ and increased $R_{\mathrm{t}}$ in unstimulated and insulin-stimulated cells and, even after stimulation with insulin, only negligible currents persisted in the presence of amiloride (Figure 1). The insulin-induced augmentation of $I_{\mathrm{Eq}}$ must therefore reflect stimulation of ENaC-mediated $\mathrm{Na}^{+}$absorption. Interestingly, insulin also increased the value of $R_{\mathrm{t}}$ measured in the presence of amiloride (Figure 1), indicating that this hormone must have other effects on these cells (e.g. increasing paracellular resistance). The physiological basis of this action was not investigated.

\section{Insulin-induced phosphorylation of endogenous proteins}

Insulin (20 nM, basolateral) increased the cellular abundance of the $\mathrm{Ser}^{473}$-phosphorylated PKB without altering the overall abundance of this protein (Figure 2A,B) and this result shows that insulin evokes PKB-Ser ${ }^{473}$ phosphorylation. This response reached a maximum after 15-30 min and, although there was some decline from this peak 


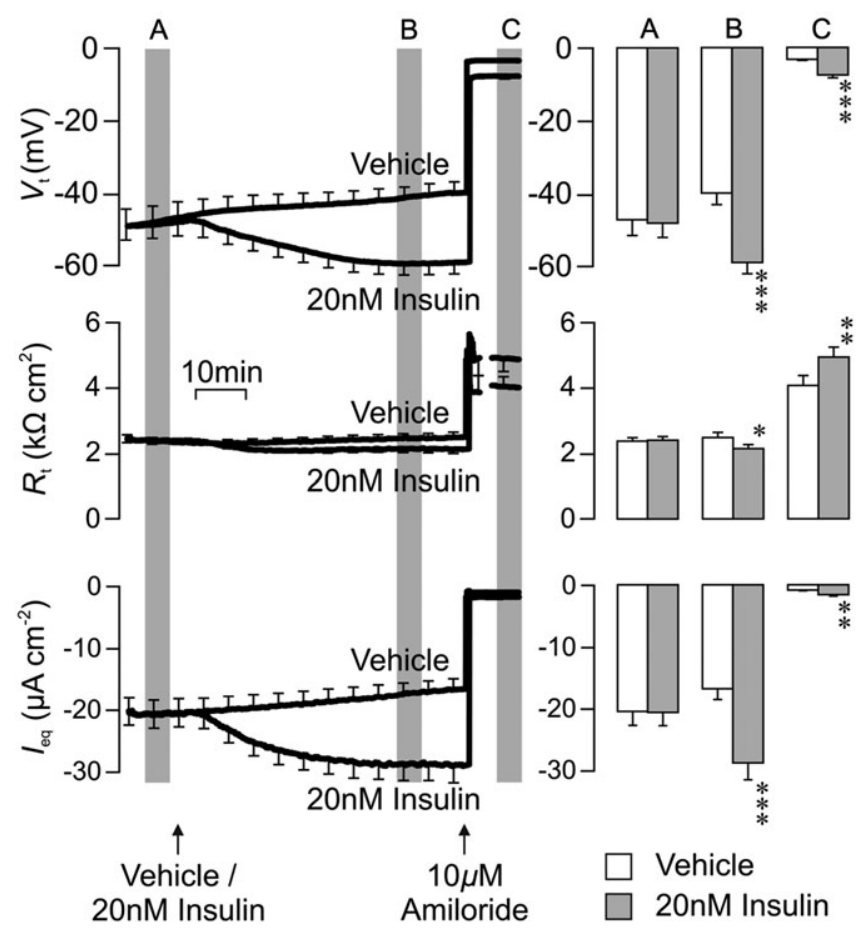

Figure 1

The electrometric response to insulin. Cells grown to confluence on Snapwell membranes were mounted in Ussing chambers so that $V_{\mathrm{t}}$ (upper panels), $R_{\mathrm{t}}$ (middle panels) and $I_{\mathrm{Eq}}$ (lower panels) could be recorded (see Methods). Because these experiments $(n=8)$ were all undertaken using two parallel Ussing chamber systems, data were recorded simultaneously from pairs of age-matched cultures at identical passage. After an initial equilibration period, the cells were exposed to basolateral insulin $(20 \mathrm{nM})$ or to solvent vehicle (arrow) and amiloride $(10 \mu \mathrm{M})$ was then added to the apical bath after a further $60 \mathrm{~min}$ had elapsed. The right hand panels all show the mean values of $V_{\mathrm{t}}, R_{\mathrm{t}}$ and $I_{\mathrm{Eq}}$ measured during (A) the initial equilibration period; (B) once the response to insulin was fully established; and (C) finally after the cells had stabilized in the presence of amiloride. These sampling periods are indicated by the shaded bars. All data are mean \pm SEM and asterisks denote statistically significant (Student's paired $t$-test) effects of insulin stimulation $\left({ }^{*} P<0.05,{ }^{* *} P<0.02\right.$, $\left.{ }^{* * *} P<0.01\right)$.

value, increased phosphorylation of PKB-Ser ${ }^{473}$ persisted for at least $6 \mathrm{~h}$ (Figure 2A,B). As the phosphorylation of this residue is dependent upon PI3K (Bayascas and Alessi, 2005), this result shows that insulin normally activates this phospholipid kinase (see review, Cohen, 2006). Insulin (20 nM, basolateral) also increased the abundance of $\mathrm{Thr}^{346 / 356 / 366}$ phosphorylated NDRG1 and this response, in common with the phosphorylation of PKB-Ser ${ }^{473}$, occurred with no change in the overall expression of this protein. The insulin-induced phosphorylation of these residues followed a very similar time course to the phosphorylation of PKB-Ser ${ }^{473}$ (Figure 2C,D) and, because NDRG1-Thr ${ }^{346 / 356 / 366}$ phosphorylation is catalyzed by SGK1 and not by other related kinases, including PKB (Murray et al., 2005a,b), this result shows that insulin also activates SGK1 (Cohen, 2006). As insulin had no effect upon the overall abundance of PKB or NDRG1 (Figure 2A-D), in all subsequent experiments changes to the cellular abundance of the $\mathrm{Ser}^{473}$ - and $\mathrm{Thr}^{346 / 356 / 366}$ phosphorylated forms of these proteins were assumed to be a reliable biomarker of increased phoshorylation of these residues. All such data were normalized to the phosphoprotein abundances measured in hormone-deprived cells. We did, however, continue to monitor the overall expression of PKB and NDRG1 in all experiments (data not shown).

PI3K-mediated phosphorylation of PKB-Ser ${ }^{473}$ is an important part of the mechanism that allows hormones to activate this protein kinase (Bayascas and Alessi, 2005; Cohen, 2006); therefore, we also explored the effects of insulin on the phosphorylation of PRAS40-Ser ${ }^{246}$, an endogenous PKB substrate (Kovacina et al., 2003). Analysis of the data derived from these experiments showed that insulin (20 nM, $30 \mathrm{~min}$ ) did increase the abundance of Ser $^{246}$-phosphorylated PRAS40 (Figure 2E,F) but also established that this response coincided with a small $(\sim 20 \%)$ fall in the overall expression of PRAS40 (Figure 2E,G). It is therefore possible that the phosphorylation of PRAS40-Ser ${ }^{246}$ targets this protein for degradation. However, in the present context, the most significant result of this observation is that it implies that changes to the abundance of Ser ${ }^{246}$ phosphorylated PRAS40 will tend to underestimate the phosphorylation of this residue. We therefore further analyzed these data by normalizing the measured abundance of Ser ${ }^{246}$-phosphorylated PRAS40 to the corresponding values of overall abundance in order to obtain an indicator of PRAS40-Ser ${ }^{246}$ phosphorylation. This analysis (Figure 2G), which was used in all subsequent studies, showed that insulin stimulates PRAS40-Ser ${ }^{246}$ phosphorylation, indicating that it does activate PKB (Kovacina et al., 2003; Cohen, 2006).

\section{Biophysical effects of PI3K inhibitors}

Figure 3A shows the results of a series of experiments that used a strictly paired experimental design (see Methods) to explore the effects of wortmannin on the electrometric response to insulin. An examination of the control data indicated that $V_{\mathrm{t}}$ tended to depolarize slightly during the first $30 \mathrm{~min}$ of the experiment (initial: $-57.0 \pm 3.4 \mathrm{mV}$; $30 \mathrm{~min}$ : $-50.2 \pm 2.1 \mathrm{mV}, P<0.05)$ and, as $R_{\mathrm{t}}$ was stable (initial: $2.1 \pm 0.2 \mathrm{k} \Omega \cdot \mathrm{cm}^{2} ; \quad 30 \mathrm{~min}: 2.2 \pm$ $\left.0.2 \mathrm{k} \Omega \cdot \mathrm{cm}^{2}\right)$, this led to an apparently spontaneous $(\sim 15 \%)$ decline in $I_{\mathrm{Eq}}$ (Figure $\left.3 \mathrm{~A}\right)$. However, despite this effect, wortmannin consistently inhibited $I_{\mathrm{Eq}}$ and, after $\sim 30 \mathrm{~min}$ exposure to this substance, this 

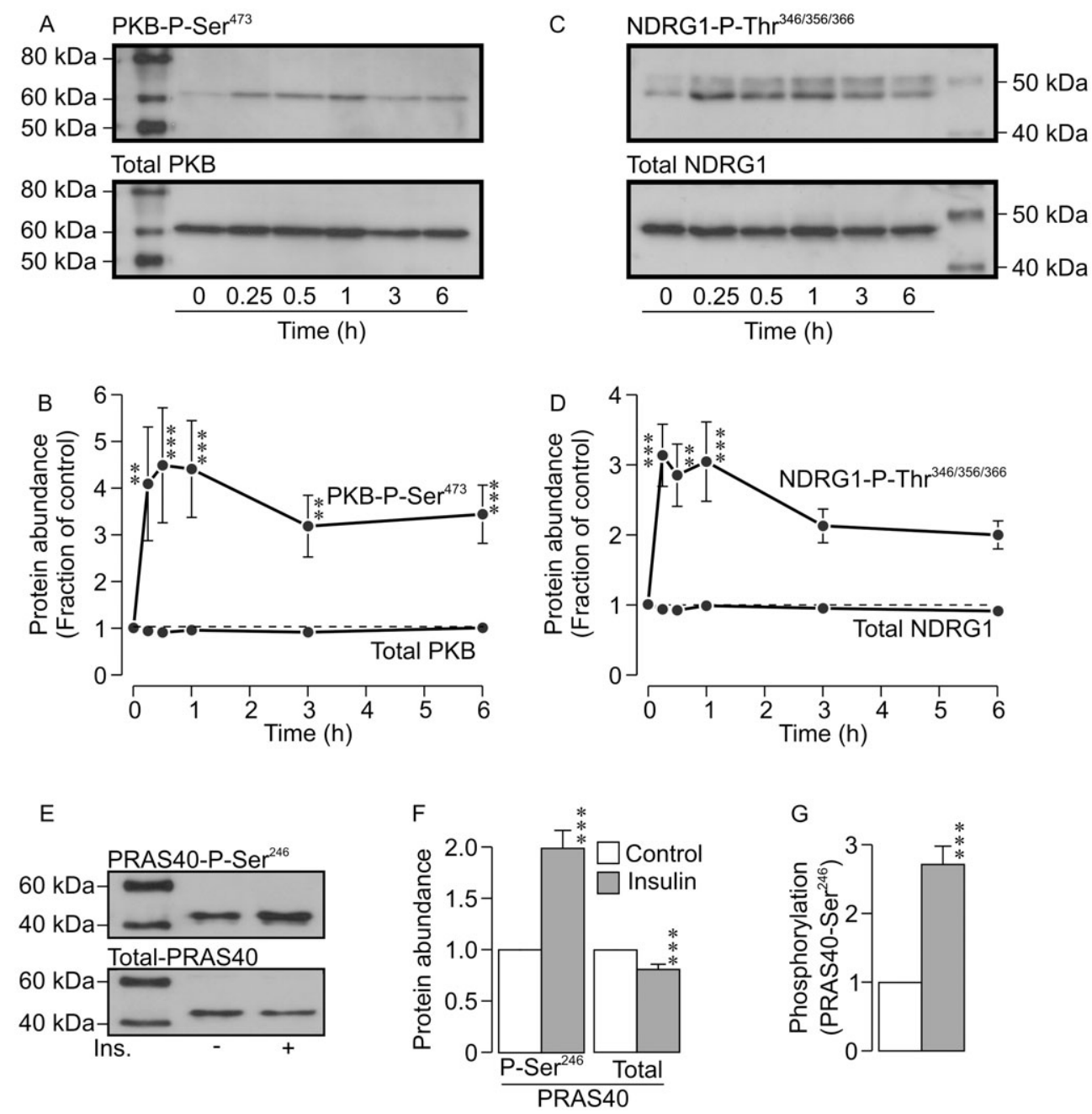

\section{Figure 2}

Insulin-evoked phosphorylation of protein kinase B (PKB) Ser ${ }^{473}$, n-myc downstream regulated gene 1 (NDRG1) Thr ${ }^{346 / 356 / 366}$ and 40 kDa proline-rich substrate of Akt (PKB) (PRAS40) Ser ${ }^{246}$. (A) Typical Western blots showing the effects of insulin (20 nM, 0-6 h) on the cellular abundance of $\mathrm{Ser}^{473}$-phosphorylated and total PKB. (B) Densitometric analysis showing the pooled data from five such experiments. (C) Western blots showing the effects of $20 \mathrm{nM}$ insulin (0-6 h) on the cellular abundance of Thr $\mathrm{r}^{346 / 356 / 366}$-phosphorylated and total NDRG1. (D) Densitometric analysis showing the pooled data from five such experiments. All data are mean \pm SEM. (E) Typical Western blots showing the effects of insulin $\left(20 \mathrm{nM}, 30 \mathrm{~min}\right.$ ) on the cellular abundance of Ser ${ }^{246}$-phosphorylated and total PRAS40. (F) Densitometric analysis showing the pooled data from a total of 28 such experiments. (G) Further analysis of these data in which the measured abundance of Ser ${ }^{246}$-phosphorylated PRAS40 was normalized to the overall abundance of this protein. Asterisks denote statistically significant effects of insulin $\left({ }^{* *} P<0.002,{ }^{* \star *} P<0.001\right)$ determined by one-way ANOVA Bonferroni post hoc test (B and D) or Student's paired $t$-test ( $F$ and $G$ ).

current had decayed to $50.7 \pm 2.7 \%(P<0.001)$ of the corresponding control value (Figure $3 \mathrm{~A}$ ). Wortmannin had no effect on $R_{\mathrm{t}}$ over this initial period (initial: $2.0 \pm 0.2 \mathrm{k} \Omega \cdot \mathrm{cm}^{2} ; 30 \mathrm{~min}: 2.2 \pm 0.2 \mathrm{k} \Omega \cdot \mathrm{cm}^{2}$ ) and this suppression of basal current was therefore due to a depolarization of $V_{\mathrm{t}}$ (initial: $-52.6 \pm$ $4.9 \mathrm{mV}$; $30 \mathrm{~min}:-21.8 \pm 2.4 \mathrm{mV}, P<0.001)$. While the control data confirmed that insulin normally enhances $I_{\mathrm{Eq}}$ (Figure $3 \mathrm{~A}$ ) by hyperpolarizing $V_{\mathrm{t}}$ with only a very small effect on $R_{\mathrm{t}}$, insulin had no effect upon $I_{\mathrm{Eq}}$ in wortmannin-treated cells (Figure $3 \mathrm{~A}$ ). It is therefore clear that this inhibitor of PI3K abolished the electrometric response to insulin.
However, analysis of the raw data recorded from wortmannin-treated cells showed that $V_{\mathrm{t}}$ and $R_{\mathrm{t}}$ declined substantially during exposure to insulin so that, after $60 \mathrm{~min}$ exposure to this hormone, these parameters had decayed to $-3.6 \pm 2.0 \mathrm{mV}(P<$ $0.001)$ and $0.5 \pm 0.2 \mathrm{k} \Omega \cdot \mathrm{cm}^{2}(P<0.001)$ respectively. In contrast, $R_{\mathrm{t}}$ and $V_{\mathrm{t}}$ were normally stable, as the values measured in control cells that had been exposed to insulin for $60 \mathrm{~min}$ were $2.2 \pm 0.1 \mathrm{k} \Omega \cdot \mathrm{cm}^{2}$ and $-54.3 \pm 5.3 \mathrm{mV}$ respectively. At the end of the experiments all cells were exposed to apical amiloride $(10 \mu \mathrm{M})$, normally this reduced $I_{\mathrm{Eq}}$ to -1.4 $\pm 0.1 \mu \mathrm{A} \cdot \mathrm{cm}^{-2}(>95 \%$ inhibition, $P<0.001$, 

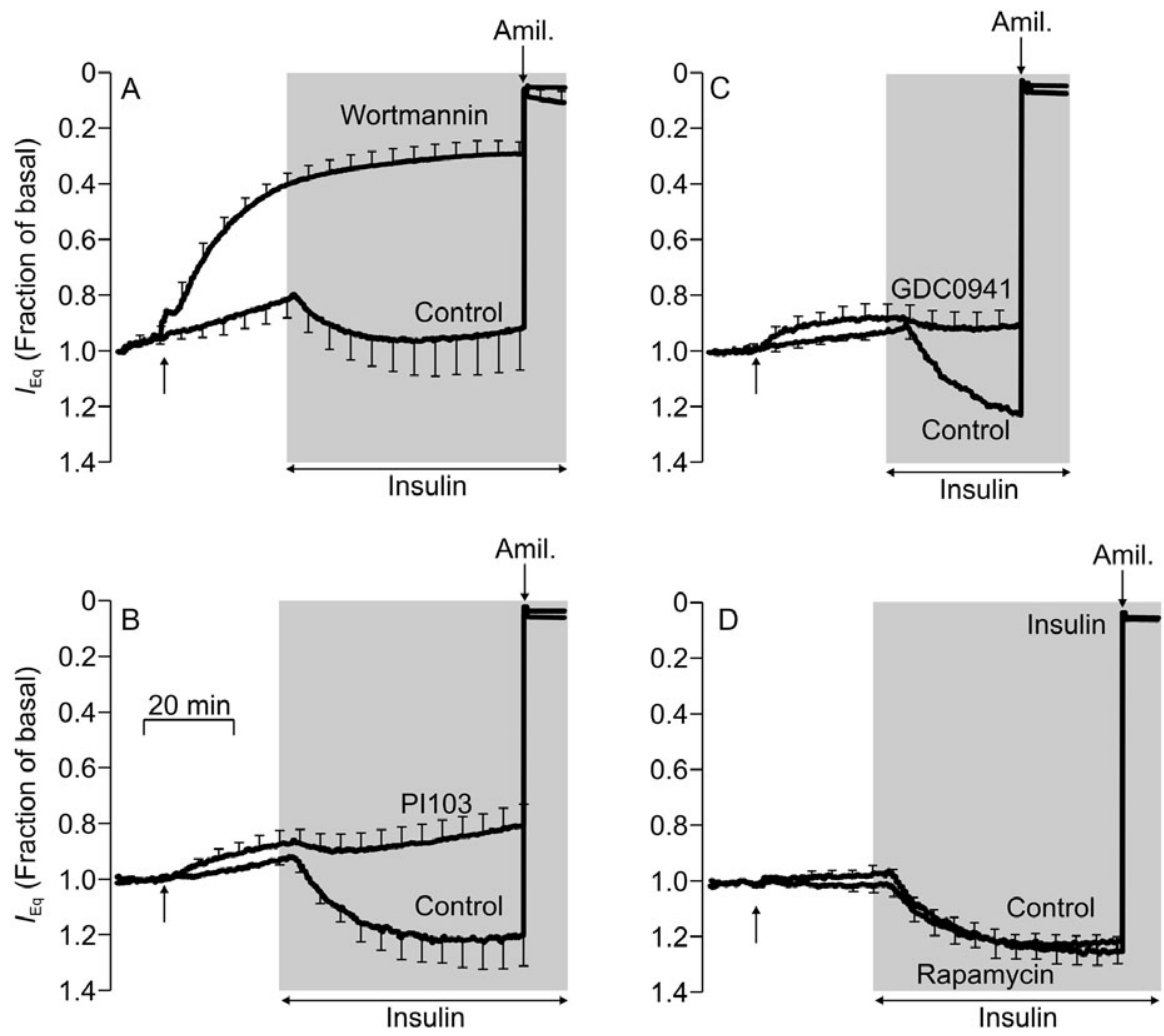

\section{Figure 3}

Effects of kinase inhibitors on $I_{\text {Eq }}$. In each experiment, $V_{\mathrm{t}}$ and $R_{\mathrm{t}}$ were recorded simultaneously from pairs of age-matched cells at identical passage and the arrows indicate the addition of either the appropriate test substances or solvent vehicle (control) to the apical and basolateral baths. After $30 \mathrm{~min}$, cells were exposed to insulin $(20 \mathrm{nM}$, basolateral, shaded areas) and experiments were finally terminated by adding $10 \mu \mathrm{M}$ amiloride to the apical bath (right hand arrows, Amil). Once recordings were complete, values of $I_{\mathrm{Eq}}$ were calculated, normalized to the magnitude of the basal current measured at the onset of the experiment and presented as mean \pm SEM. (A) Effects of wortmannin $(0.1 \mu \mathrm{M})$; basal $l_{\mathrm{Eq}}(\mathrm{Control})$ : -27.5 $\pm 2.7 \mu \mathrm{A} \cdot \mathrm{cm}^{-2}$; basal $l_{\mathrm{Eq}}$ (test): $-25.4 \pm 3.6 \mu \mathrm{A} \cdot \mathrm{cm}^{-2} ;(n=5)$. (B) Effects of PI103 (1 $\left.\mu \mathrm{M}\right) ;$ basal $l_{\mathrm{Eq}}$ (control): $-26.1 \pm 5.0 \mu \mathrm{A} \cdot \mathrm{cm}{ }^{-2} ; \mathrm{basal} l_{\mathrm{Eq}}$ (test): $-30.0 \pm 6.1 \mu \mathrm{A} \cdot \mathrm{cm}^{-2} ;(n=6)$. (C) Effects of GDC-0941 $(1 \mu \mathrm{M}) ;$ basal $l_{\mathrm{Eq}}$ (control): $-20.7 \pm 1.3 \mu \mathrm{A} \cdot \mathrm{cm}^{-2} ; \mathrm{basal} l_{\mathrm{Eq}}(\mathrm{test}):-20.9 \pm 3.3 \mu \mathrm{A} \cdot \mathrm{cm}^{-2} ;(n$ $=5)$. (D) Effects of rapamycin $(0.1 \mu \mathrm{M})$; basal $I_{\mathrm{Eq}}$ (control): $-27.8 \pm 3.4 \mu \mathrm{A} \cdot \mathrm{cm}^{-2}$; basal $I_{\mathrm{Eq}}($ test $):-23.3 \pm 4.1 \mu \mathrm{A} \cdot \mathrm{cm}-2 ;(n=5)$.

Figure 3A) and increased $R_{\mathrm{t}}$ to $3.9 \pm 0.6 \mathrm{k} \Omega \cdot \mathrm{cm}^{2}(P<$ $0.001)$. However, although amiloride abolished the small current that persisted in the presence of wortmannin (Figure 3A), this inhibition occurred with no increase in $R_{\mathrm{t}}\left(0.4 \pm 0.2 \mathrm{k} \Omega \cdot \mathrm{cm}^{2}\right)$. Wortmannin therefore appears to cause loss of epithelial integrity.

Figure 3B,C show data from experiments in which the same protocol was used to explore the effects of PI103 and GDC-0941. Once again, the control data confirm that hormone-deprived cells generate inwardly directed $I_{\mathrm{Eq}}$ and show that insulin normally increases the magnitude of this current (Figure 3B,C). An examination of the underlying data showed that this control response was due to a hyperpolarization of $V_{\mathrm{t}}$ that was associated with a small fall in $R_{\mathrm{t}}$. Although PI103 and GDC-0941 did cause slight inhibition of $I_{\mathrm{Eq}}$ (Figure 3B,C), the currents measured after $30 \mathrm{~min}$ exposure to these compounds did not differ significantly from control (PI103: $94.3 \pm 5.0 \%$ of control; GDC-0941: $94.6 \pm$ $5.1 \%$ of control) and the corresponding values of $R_{\mathrm{t}}$
(PI103: $2.1 \pm 0.04 \mathrm{k} \Omega \cdot \mathrm{cm}^{2}$; GDC-0941: $2.4 \pm$ $0.2 \mathrm{k} \Omega \cdot \mathrm{cm}^{2}$ ) were also essentially identical to control $\left(2.1 \pm 0.2 \mathrm{k} \Omega \cdot \mathrm{cm}^{2}\right.$ and $2.3 \pm 0.2 \mathrm{k} \Omega \cdot \mathrm{cm}^{2}$ respectively). These compounds, in contrast to wortmannin, therefore had only very small effects on the electrical properties of hormone-deprived cells. Although insulin slightly increased the magnitude of $I_{\mathrm{Eq}}$ in cells that had been treated with PI103 (Figure 3B) or GDC-0941 (Figure 3C), the magnitude of these responses were $<10 \%$ of control. Moreover, the values of $R_{\mathrm{t}}$ measured at the end of these experiments were also similar to control (not shown) and so, although PI103 and GDC-0941 have almost no effect upon the basal $I_{\mathrm{Eq}}$, they inhibit $(-90 \%)$ the response to insulin without affecting epithelial integrity.

\section{Biophysical effects of rapamycin}

Although often referred to as PI3K inhibitors, wortmannin (Brunn et al., 1993) and PI103 (Raynaud et al., 2007) both inhibit TORC1 and we therefore 

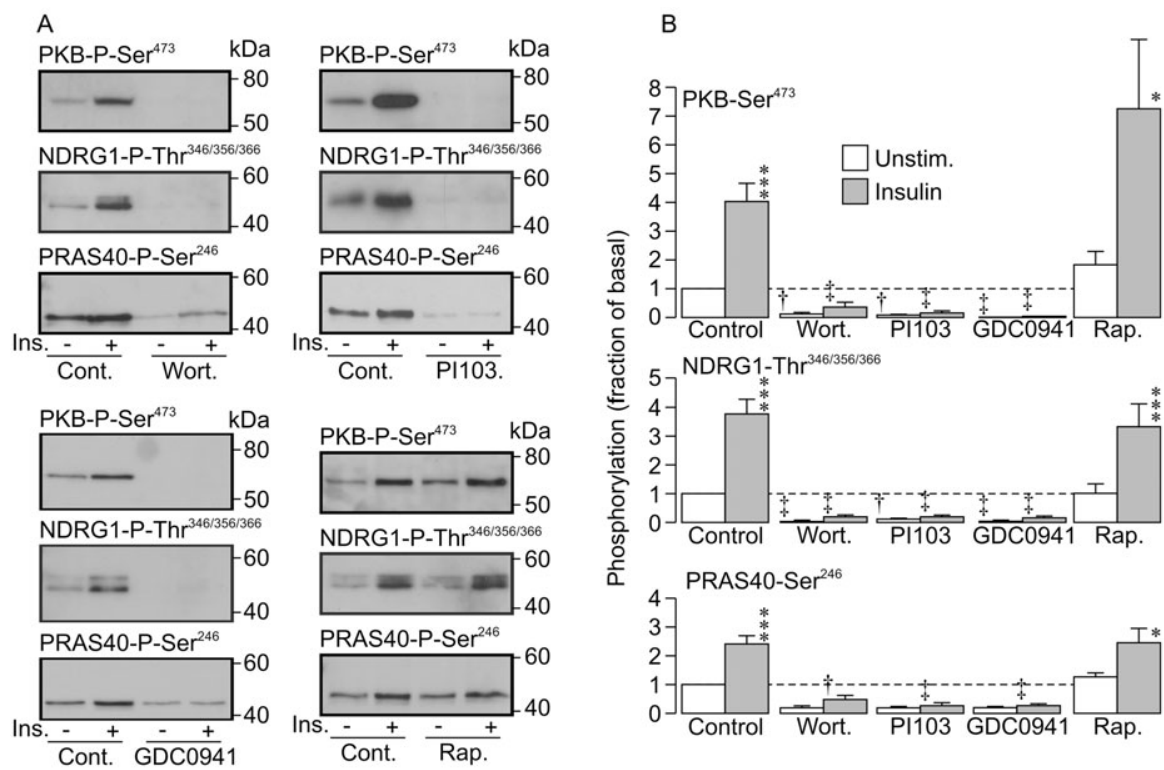

\section{Figure 4}

Effects of kinase inhbitors on the phosphorylation of endogenous proteins. (A) Each panel shows the result of an experiment in which age-matched cells at identical passage were either maintained under control conditions (i.e. exposed to solvent vehicle) or exposed to $0.1 \mu \mathrm{M}$ wortmannin, $1 \mu \mathrm{M}$ PI 103, $1 \mu \mathrm{M}$ GDC-0941 or $0.1 \mu \mathrm{M}$ rapamycin (30 min pre-incubation). Control and inhibitor-treated cells were then incubated for a further $30 \mathrm{~min}$ either in hormone-free medium or in medium supplemented with $20 \mathrm{nM}$ insulin (basolateral). Aliquots $(40 \mu \mathrm{g})$ of extracted protein were then subjected to Western analysis using antibodies against the $\operatorname{Ser}^{473}$-phosphorylated form of protein kinase B (PKB-Ser ${ }^{473}$, upper panels), the $\mathrm{Thr}^{346 / 356 / 366}$-phosphorylated form of the n-myc downstream regulated gene 1-encoded protein (NDRG1-Thr ${ }^{346 / 356 / 366}$, middle panels) and the $\mathrm{Ser}^{246}$-phosphorylated form of the $40 \mathrm{kDa}$ proline rich Akt (PKB) substrate (PRAS40-Ser ${ }^{246}$, lower panels). (B) Densitometric analysis showing the pooled data derived from all such experiments ( $n=6$ for each). Data are mean \pm SEM and asterisks denote statistically significant effects of insulin on the phosphorylation of these substrates $\left({ }^{*} P<0.05,{ }^{* *} P<0.001\right.$, Student's paired $t$-test), while daggers denote statistically significant effects of the inhibitors on the phosphorylation of each substrate under hormone-free conditions and insulin-stimulated conditions $(\dagger P<0.05, \ddagger P<0.01$; one-way ANOVA/Bonferroni post hoc test).

also explored the effects of rapamycin $(0.1 \mu \mathrm{M}$, $30 \mathrm{~min})$, a selective inhibitor of this signalling complex (Bain et al., 2007), to ensure that effects on TORC1 did not underlie any of the effects reported here. Rapamycin had no effect upon the $I_{\mathrm{Eq}}$ in hormone-deprived cells and insulin-stimulated cells (Figure 3D) and also had no effect upon $V_{\mathrm{t}}$ and $R_{\mathrm{t}}$ (not shown).

\section{Effects of PI3K-inhibitors on the phosphorylation of endogenous proteins}

The data in Figure 4 confirm that insulin $(20 \mathrm{nM}$, 30 min) normally evokes phosphorylation of PKB$\mathrm{Ser}^{473}$, NDRG1-Thr ${ }^{346 / 356 / 366}$ and PRAS40-Ser ${ }^{246}$ and show that wortmanin, PI103 and GDC-0941 caused essentially complete dephosphorylation of these residues in both hormone-deprived and insulinstimulated cells. Because the phosphorylation of this residue is clearly dependent upon PI3K (Bayascas and Alessi, 2005), this result shows that all three compounds essentially cause complete inhibition of this regulatory kinase.

\section{Effects of rapamycin on the phosphorylation of endogenous proteins}

Rapamycin did not alter the phosphorylation of PKB-Ser ${ }^{473}$, NDRG1-Thr ${ }^{346 / 356 / 366}$ and PRAS40-Ser ${ }^{246}$ in hormone-deprived or insulin-stimulated cells (Figure 4). Additional experiments explored the effects of rapamycin on the phosphorylation of a residue $\left(\mathrm{P} 70-\mathrm{S} 6 \mathrm{~K}-\mathrm{Thr}^{389}\right)$ that has been identified as a TORC1 substrate (Proud, 2007). These studies ( $n=$ 4) revealed basal phosphorylation of P70-S6K-Thr ${ }^{389}$ in hormone-deprived cells and, as anticipated, insulin $(20 \mathrm{nM}, 30 \mathrm{~min})$ increased the abundance of the $\mathrm{Thr}^{389}$-phosphorylated S6K but had no effect on overall expression. Insulin therefore activates TORC1 in these cells (Proud, 2007). Rapamycin caused essentially complete dephosphorylation of P70-S6K-Thr ${ }^{389}$ in hormone-deprived and insulinstimulated cells, indicating that this compound fully inactivates TORC1 (data not shown).

\section{Electrometric effects of GSK650394A}

Experiments in which hormone-deprived cells were acutely exposed to GSK650394A (1-10 $\mu \mathrm{M}$, added to 


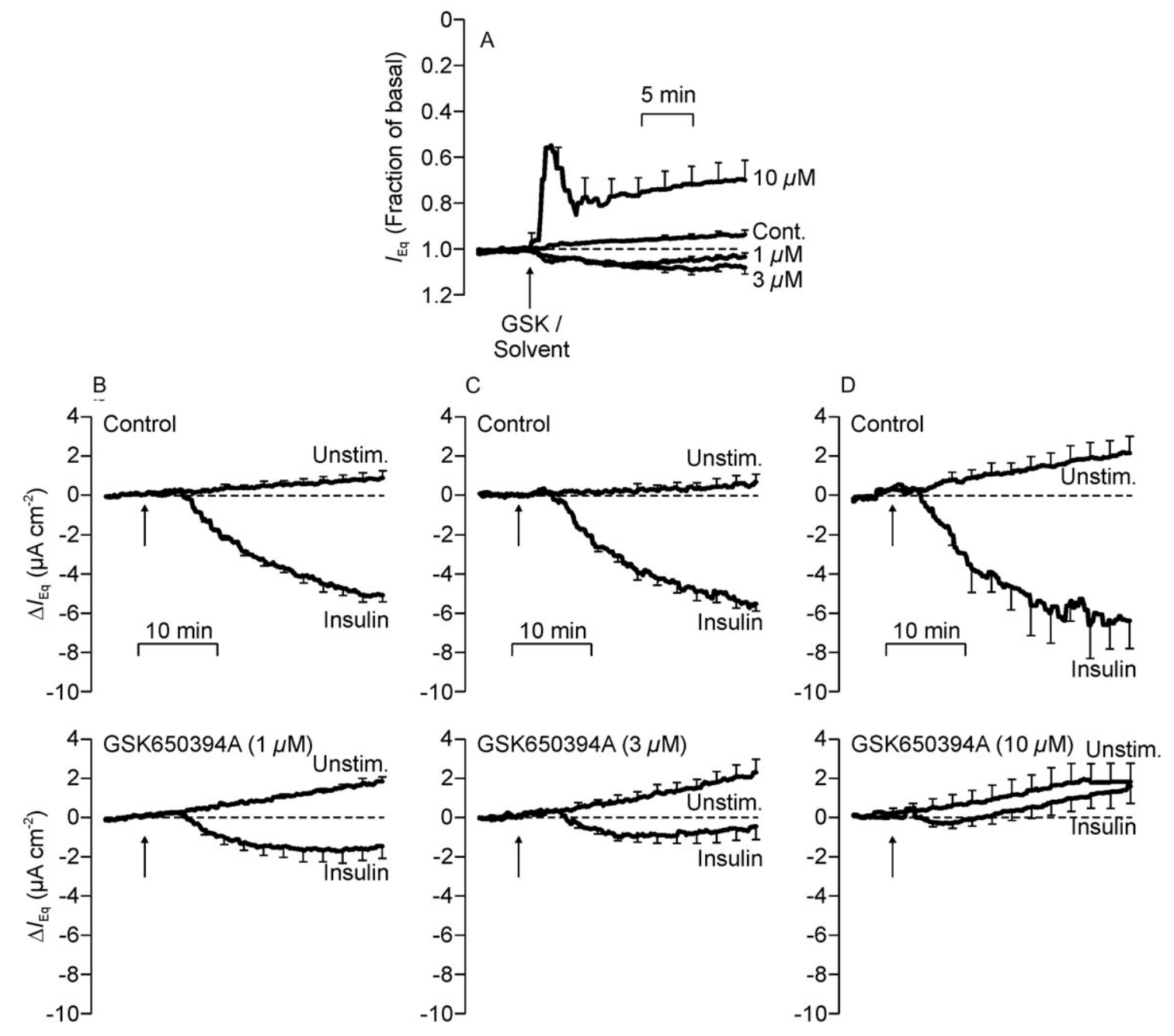

\section{Figure 5}

Effects of GSK650394A (GSK) upon the current recorded from hormone-deprived (A) and insulin-stimulated (B-D) cells. (A) Currents ( $n=5$ ) were initially recorded from hormone-deprived cells under standard conditions and all data were then normalized to the magnitude of the basal current (control: $-16.8 \pm 1.8 \mu \mathrm{A} \cdot \mathrm{cm}^{-2} ; 1 \mu \mathrm{M} \mathrm{GSK}:-12.2 \pm 2.1 \mu \mathrm{A} \cdot \mathrm{cm}^{-2} ; 3 \mu \mathrm{M} \mathrm{GSK}:-18.1 \pm 3.1 \mu \mathrm{A} \cdot \mathrm{cm}^{-2} ; 10 \mu \mathrm{M} \mathrm{GSK}:-21.0 \pm 3.7 \mu \mathrm{A} \cdot \mathrm{cm}^{-2}$ ) measured before GSK650394A $(1-10 \mu \mathrm{M})$ or solvent vehicle (control) was added as indicated by the arrow. (B-D) The upper part of each panel shows control data derived from unstimulated and insulin-stimulated $(20 \mathrm{nM}$, arrow) cells while the lower part shows equivalent data derived from age-matched cells at identical passage that had been pre-treated with $1 \mu \mathrm{M}$ (B), $3 \mu \mathrm{M}$ (C) or $10 \mu \mathrm{M}$ (D) GSK650394A (30 min pre-incubation, $n=6)$. These data are shown as change in $l_{\mathrm{Eq}}$ from the value measured in the first $5 \mathrm{~min}$ of the experimental period $\left(\Delta l_{\mathrm{Eq},}\right.$ mean $\left.\pm \mathrm{SEM}\right)$.

the apical and basolateral baths), an inhibitor of SGK1 (Sherk et al., 2008), showed that this compound had no significant effect upon the $I_{\mathrm{Eq}}$ when used at $1 \mu \mathrm{M}$ and $3 \mu \mathrm{M}$ (Figure 5A). However, when used at $10 \mu \mathrm{M}$, GSK650394A rapidly (2-3 min) reduced $I_{\mathrm{Eq}}$ to a value that was $\sim 60 \%$ of the initial, control value $(P<0.02$, Figure $5 \mathrm{~A})$. However, this effect was transient because $I_{\mathrm{Eq}}$ subsequently recovered to a plateau value that was $\sim 70 \%(P<0.05)$ of that recorded at the onset of the experiment (Figure 5A). Figure 5B-C shows the results of experiments that explored the effects of GSK650394A upon the electrometric response to insulin. These experiments were undertaken using a very strictly paired experimental design in order to ensure that variability between cells at different passage number did not confound data analysis. Each such experiment therefore involved simultaneously recording $I_{\mathrm{Eq}}$ from four confluent cultures so that we could monitor spontaneously developing and insulinevoked changes in $I_{\mathrm{Eq}}$ in both control and GSK650394A-treated cells. Responses to insulin were quantified by subtracting the change in $I_{\mathrm{Eq}}$ measured in control cells from the change that developed during exposure to insulin and this, in turn, allowed the effects of GSK650394A to be quantified. Data obtained in this way confirm that insulin normally enhances $I_{\mathrm{Eq}}$ and, while this 

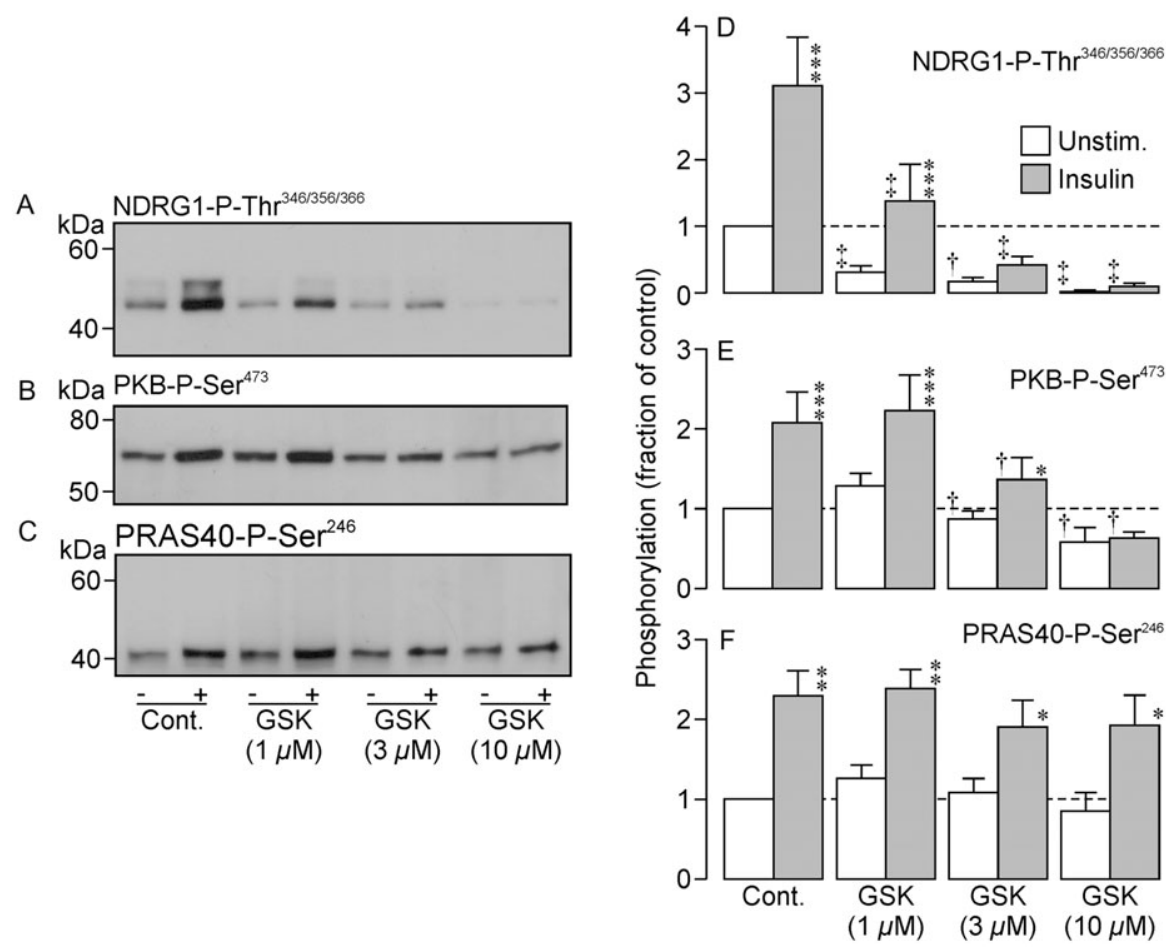

\section{Figure 6}

Effects of GSK650394A (GSK) on the phosphorylation of the protein encoded by n-myc downstream regulated gene 1 (NDRG1-Thr ${ }^{346 / 356 / 366}$ ), protein kinase B (PKB)-Ser ${ }^{473}$ and the $40 \mathrm{kDa}$ proline-rich substrate of Akt (PKB) (PRAS40) -Ser ${ }^{246}$. Age-matched cells at identical passage were either maintained in hormone-free medium (Unstim) or exposed to insulin ( $20 \mathrm{nM}, 30 \mathrm{~min}$ ) under control conditions or in the presence of GSK650394A (GSK, $1 \mu \mathrm{M}, 3 \mu \mathrm{M}$ or $10 \mu \mathrm{M}, 30$ min pre-incubation). Aliquots of extracted protein $(40 \mu \mathrm{g})$ were subjected to Western analysis using antibodies against the Thr ${ }^{346 / 356 / 366}$-phosphorylated form of NDRG1 (A, D), the Ser ${ }^{473}$-phosphorylated form of PKB (B, E) or the Ser ${ }^{246}$ phosphorylated form of PRAS40 (C, F). The left hand panels (A-C) show typical blots illustrating the effects of GSK650394A on the phosphorylation of these residues while the densitometric analysis presented in the right hand panels (D-F) shows pooled data (mean \pm SEM) derived from the entire series of experiments ( $n=6$ for each). Asterisks denote statistically significant effects of insulin on the phosphorylation of NDRG1$\mathrm{Thr}^{346 / 356 / 366}\left({ }^{*} P<0.05,{ }^{* *} P<0.02 ;{ }^{* * *} P<0.001\right.$, Student's paired $t$-test), while daggers denote statistically significant effects of GSK650394A on the phosphorylation of this protein in hormone-deprived or insulin-stimulated cells $(\dagger P<0.05, \ddagger P<0.001$, two-way ANOVA/Bonferroni post hoc test).

response did persist in the presence of $1 \mu \mathrm{M}$ (Figure 5B) and $3 \mu \mathrm{M}$ (Figure 5C) GSK650394A, this substance did cause some inhibition $(1 \mu \mathrm{M}: 44.5 \pm$ 7.6\% inhibition, $P<0.01 ; 3 \mu \mathrm{M}: 54.8 \pm 1.5 \%$ inhibition, $P<0.001$ ). GSK650394A caused essentially complete block of this response $(96.9 \pm 5.6 \%$ inhibition, $P<0.02$ ) at $10 \mu \mathrm{M}$ (Figure 5D).

\section{Effects of GSK650394A on the}

phosphorylation of endogenous proteins

GSK650394A (1-10 $\mu \mathrm{M})$ had no effect on the overall expression of the NDRG1 protein (not shown) but caused a concentration-dependent decline in NDRG1-Thr ${ }^{346 / 356 / 366}$ phosphorylation in hormonedeprived and insulin-stimulated cells, and this effect was essentially complete at $10 \mu \mathrm{M}$ (Figure 6A,D). GSK650394A $(1-10 \mu \mathrm{M})$ also had no effect on the overall expression of PKB (not shown) and did not alter the abundance of Ser ${ }^{473}$-phosphorylated PKB in hormone-deprived cells (Figure 6B). However,
GSK650394A did inhibit the insulin-induced phosphorylation of PKB-Ser ${ }^{473}$ at $3 \mu \mathrm{M}$, and essentially abolished this response at $10 \mu \mathrm{M}$ (Figure 6B,E) and, because the phosphorylation of PKB-Ser ${ }^{473}$ is dependent upon PI3K (Bayascas and Alessi, 2005), this finding suggests that GSK650394A may prevent the insulin-induced activation of PI3K. However, despite this effect, GSK650394A $(1-10 \mu \mathrm{M})$ did not alter the phosphorylation of PRAS40-Ser ${ }^{246}$ in hormone-deprived cells and did not prevent the insulin-induced phosphorylation of this residue (Figure 6C,F). It thus appears that $10 \mu \mathrm{M}$ GSK650394A blocks signalling via SGK1 but not PKB (see also Sherk et al., 2008).

\section{Electrometric effects of Akti-1/2}

Acutely exposing cells to Akti-1/2 $(1-10 \mu \mathrm{M}$, apical and basolateral) had no discernible effect upon $I_{\mathrm{Eq}}$ at 1 and $3 \mu \mathrm{M}$ (Figure 7A). However, $10 \mu \mathrm{M}$ Akti-1/2 caused a small $(\sim 25 \%)$ but significant $(P<0.01)$ 

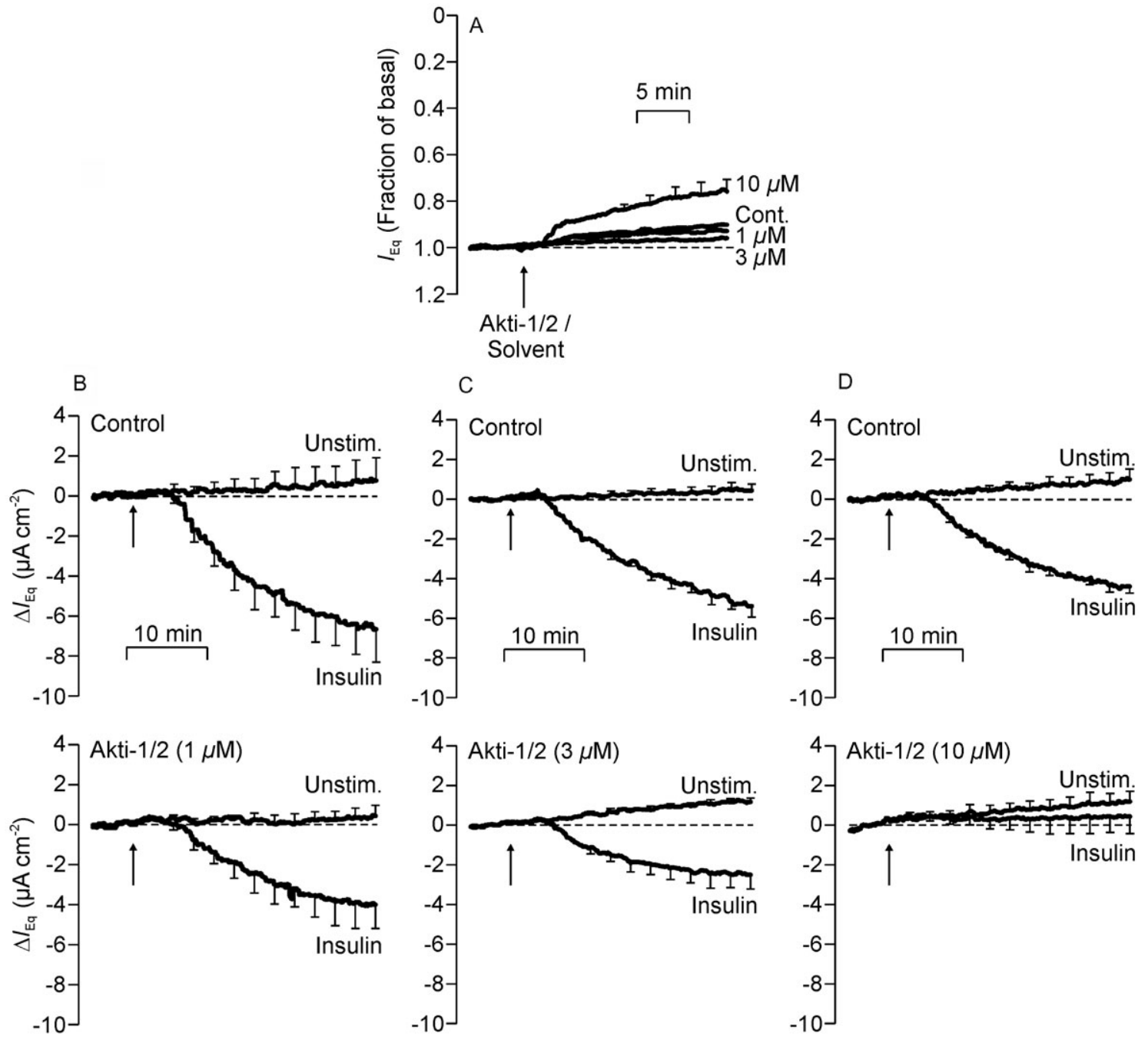

Figure 7

Effects of Akti-1/2 on the current recorded from hormone-deprived (A) and insulin-stimulated cells (B-D). (A) Currents were initially recorded from hormone-deprived cells under standard conditions and all data are normalized to the magnitude of this basal current (control: $-17.8 \pm$ $1.7 \mu \mathrm{A} \cdot \mathrm{cm}^{-2} ; 1 \mu \mathrm{M}$ Akti-1/2: $-20.3 \pm 2.0 \mu \mathrm{A} \cdot \mathrm{cm}^{-2} ; 3 \mu \mathrm{M}$ Akti-1/2: $-15.3 \pm 0.9 \mu \mathrm{A} \cdot \mathrm{cm}^{-2} ; 10 \mu \mathrm{M}$ Akti-1/2: $\left.-15.1 \pm 3.3 \mu \mathrm{A} \cdot \mathrm{cm}^{-2}\right)$ that was recorded over the 5 min period preceding the addition of Akti-1/2 (1-10 $\mu \mathrm{M})$ or solvent vehicle (control) as indicated by the arrow $(n=5$ for each). (B-D) The upper part of each panel shows data derived from unstimulated and insulin-stimulated $(20 \mathrm{nM}$, arrow) control cells while the lower panels show equivalent data derived from age-matched cells at identical passage that had been pre-treated with $1 \mu \mathrm{M}$ (B), $3 \mu \mathrm{M}(\mathrm{C})$ or $10 \mu \mathrm{M}$ (D) Akti-1/2 (30 min pre-incubation, $n=6)$. These data are shown as change in $l_{\mathrm{Eq}}$ from the value measured in the first 5 min of the experimental period $\left(\Delta l_{\text {Eq, }}\right.$ mean $\left.\pm \mathrm{SEM}\right)$.

inhibition of the basal current that became apparent after a latency period of $\sim 2 \mathrm{~min}$ and developed over the following 10-15 min (Figure 7A). Figure 7B-D shows the results of experiments that explored the effects of Akti-1/2 (1-10 $\mu \mathrm{M})$ on the insulin-induced augmentation of $I_{\mathrm{Eq}}$ using the method described previously. The control data confirm that insulin consistently increased the magnitude of this current and, although Akti-1/2 appeared to enhance the spontaneous decline in $I_{\mathrm{Eq}}$ when used at $3 \mu \mathrm{M}$ and $10 \mu \mathrm{M}$, these effects were not statistically significant. Responses to insulin were clearly seen in cells exposed to $1 \mu \mathrm{M}$ (Figure 7B) and $3 \mu \mathrm{M}$ Akti-1/2 (Figure 7C), but these were smaller than control $(1 \mu \mathrm{M}$ : $43.4 \pm 14.6 \%$ inhibition, $P<0.05 ; 3 \mu \mathrm{M}$ : 31.3 $\pm 12.5 \%$ inhibition, $P<0.05)$ and this response was essentially abolished $(80.8 \pm 7.3 \%$ inhibition, $P<$ 0.02 ) by $10 \mu \mathrm{M}$ Akti-1/2 (Figure 7D).

\section{Effects of Akti-1/2 on the phosphorylation of endogenous proteins}

Exposing cells to Akti-1/2 had no effect on the overall expression of PKB or PRAS40 (not shown) 
but did cause a concentration-dependent decline in the abundance of $\mathrm{Ser}^{473}$-phopshorylated PKB (Figure 8A,D) and $\mathrm{Ser}^{246}$-phosphorylated PRAS40 (Figure 8B,E) in both hormone-deprived and insulin-stimulated cells. Indeed, these phosphoproteins were almost undetectable after exposure to $10 \mu \mathrm{M}$ Akti-1/2, indicating essentially complete inactivation of PKB. Akti-1/2 also had no discernible effect upon the overall expression of NDRG1 (not shown) and the data in Figure 8C,F therefore show that Akti-1/2 caused concentration-dependent dephosphorylation of NDRG1-Thr ${ }^{346 / 356 / 366}$ in hormone-deprived and insulin-stimulated cells. Indeed, $10 \mu \mathrm{M}$ Akti-1/2 essentially abolished the basal phosphorylation of NDRG1-Thr ${ }^{346 / 356 / 366}$ and the response to insulin (Figure 8C and F) and, because these residues are phosphorylated by SGK1 and not by PKB (Murray et al., 2005a,b), these data show that Akti- $1 / 2$ blocks signalling via both PKB and SGK1 under the present conditions.

\section{Discussion}

\section{$\mathrm{Na}^{+}$transport in hormone-deprived cells} Hormone-deprived mpkCCD cells absorb $\mathrm{Na}^{+}$from the apical bath via an apparently spontaneous mechanism dependent upon $\mathrm{ENaC}$ and it is therefore clear that $\mathrm{Na}^{+}$absorption can occur independently of stimulating hormones, a finding that accords with data from several earlier studies of ASDN-derived cell lines (see e.g. Blazer-Yost et al., 1998; 2003; Record et al., 1998; Paunescu et al., 2000; Alvarez De La Rosa and Canessa, 2003). Analyses of extracted protein showed that hormonedeprived cells displayed basal phosphorylation of PKB-Ser ${ }^{473}$, establishing (Bayascas and Alessi, 2005) that PI3K is active under these conditions. It is therefore interesting that this regulatory kinase seems to contribute to the control of ENaC function. Early evidence of this came from the observation that LY294002, a PI3K inhibitor, blocks $\mathrm{Na}^{+}$
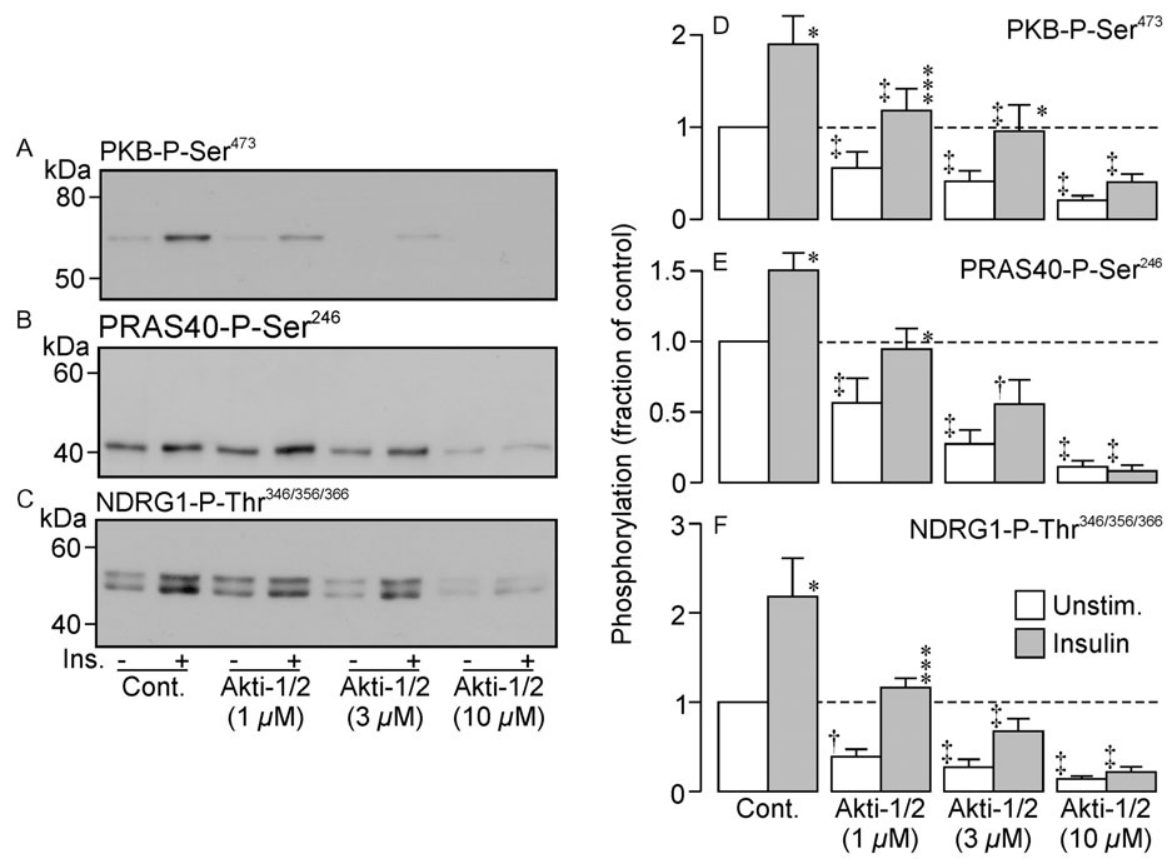

\section{Figure 8}

Effects of Akti-1/2 on the phosphorylation of protein kinase B (PKB) $-S_{e r} r^{473}$, the 40 kDa proline-rich substrate of Akt (PKB) (PRAS40) -Ser ${ }^{246}$ and the protein encoded by $\mathrm{n}$-myc downstream regulated gene 1 (NDRG1-Thr ${ }^{346 / 356 / 366}$ ). Age-matched cells at identical passage were either maintained in hormone-free medium (Unstim) or exposed to insulin ( $20 \mathrm{nM}, 30 \mathrm{~min})$. Experiments were undertaken using cells that had been exposed to the solvent vehicle (control) or to Akti-1/2 (1 $\mu \mathrm{M}, 3 \mu \mathrm{M}$ or $10 \mu \mathrm{M}, 30 \mathrm{~min}$ pre-incubation). All cells were then lysed and aliquots of extracted protein $(40 \mu \mathrm{g})$ subjected to Western analysis using antibodies against the Ser ${ }^{473}$-phosphorylated PKB (A, D), the Ser ${ }^{246}$-phosphorylated PRAS40 (B, E) or the Thr ${ }^{346 / 356 / 366}$-phosphorylated form of NDRG1 (C, F). The left-hand panels (A-C) show typical blots illustrating the effects of Akti-1/2 on the phosphorylation of these residues, while the densitometric analyses presented in the right-hand panels (D-F) show the pooled data (mean \pm SEM) from the entire series of experiments $(n=6)$. Asterisks denote statistically significant effects of insulin on the phosphorylation of these proteins $\left({ }^{*} P<0.05,{ }^{* * *} P<0.001\right.$, Student's paired $t$-test), while daggers denote statistically significant effects of Akti- $1 / 2$ on the basal phosphorylation of each substrate under hormone-free conditions or in the presence of insulin $(\dagger P<0.05, \ddagger P<0.001$, two-way ANOVA/Bonferroni post hoc test). 
absorption in hormone-deprived cells by progressively reducing the number of active $\mathrm{Na}^{+}$channels in the apical membrane (Paunescu et al., 2000). Moreover, structural studies (Schild et al., 1996) showed that each ENaC subunit contains a C-terminal PY motif that provides binding sites for the neural precursor cell expressed, developmentally down-regulated protein 4-2 (Nedd-4/2). The binding of Nedd-4/2 (Kanelis et al., 2001) to these motifs targets the ENaC channel complex for internalization and degradation and such Nedd-4/2mediated internalization/degradation of $\mathrm{ENaC}$ seems to limit the rate of $\mathrm{Na}^{+}$absorption by restricting the $\mathrm{Na}^{+}$conductance of the apical membrane $\left(G_{\mathrm{Na}}\right)$ (Debonneville et al., 2001; Wang et al., 2001; Snyder et al., 2004). PI3K contributes to this mechanism by maintaining the catalytic activity of SGK1 (Kobayashi and Cohen, 1999; Park et al., 1999), a protein kinase that prevents the interaction between Nedd-4/2 and ENaC by phosphorylating Nedd-4/2 at Ser ${ }^{342}$ and $\operatorname{Ser}^{428}$ (Debonneville et al., 2001; Wang et al., 2001; Snyder et al., 2004). PI3K inhibitors such as LY294002 are therefore thought to inhibit $\mathrm{Na}^{+}$transport by depriving the cell of SGK1 activity and thus facilitating the Nedd-4/2mediated internalization/degradation of $\mathrm{ENaC}$. However, although widely used, such small molecule kinase inhibitors almost always affect multiple targets and it is now clear that, as well as inactivating PI3K, LY294002 also inhibits TORC1, PLK1 (polo-like kinase 1), PIMK (provirus integration site for Moloney murine leukaemia virus kinase) 1 and 3, HIPK (homeodomain-interacting protein kinase) 2, GSK3 (glycogen synthase kinase 3) and CK2 (casein kinase 2) (Davies et al., 2000; Bain et al., 2007). LY294002 therefore displays poor selectivity for PI3K and its use to block signalling via this kinase is therefore no longer recommended (Bain et al., 2007). Indeed, the fact that LY294002 inhibits CK2 makes it particularly unsuitable for studies of $\mathrm{Na}^{+}$-absorbing epithelia as CK2 does appear to contribute to the control of ENaC activity (Shi et al., 2002; Bachhuber et al., 2008).

The present study therefore explored the effects of wortmannin, PI103 and GDC-0941 as these substances all appear to be relatively selective PI3K inhibitors (Bain et al., 2007; Folkes et al., 2008). The first such studies showed that wortmannin inhibited $\mathrm{Na}^{+}$absorption in hormone-deprived cells and this is consistent with the idea that PI3K is essential for the maintenance of basal $\mathrm{Na}^{+}$absorption (Paunescu et al., 2000). However, PI103 and GDC-0941 had very little effect on basal $\mathrm{Na}^{+}$transport and yet an analysis of extracted protein showed very clearly that wortmannin, PI103 and GDC-0941 all caused essentially complete dephosphorylation of PKB-
$\mathrm{Ser}^{473}$, NDRG1-Thr ${ }^{346 / 356 / 366}$ and PRAS40-Ser ${ }^{246}$. It is therefore clear that all three compounds do inactivate PI3K fully under the present conditions, and also block signalling via SGK1 and PKB, protein kinases that are important downstream targets of PI3K (Kobayashi and Cohen, 1999; Park et al., 1999; Bayascas and Alessi, 2005). The main effect of wortmannin which we now report cannot therefore be attributed to more effective inhibition of PI3K and it is therefore interesting that in vitro studies have shown that this compound can also inactivate PLK1 and smooth muscle myosin light chain kinase (SmMLCK). While we are unaware of any data implicating PLK1 in the control of epithelial $\mathrm{Na}^{+}$ absorption, it has been suggested that SmMLCK might contribute to the regulation of $\mathrm{ENaC}$ trafficking (Tokuda et al., 2002) and, because PI103 does not appear to act in this way (Bain et al., 2007), effects on SmMLCK might explain the effect of wortmannin which we now report.

Our data from cells treated with PI103 and GDC0941 show that signalling via PI3K/SGK1 does not make a major contribution to $\mathrm{Na}^{+}$absorption in hormone-deprived cells and this contrasts with earlier data (see e.g. Blazer-Yost et al., 1998; 2003; Record et al., 1998; Paunescu et al., 2000; Alvarez De La Rosa and Canessa, 2003). Data from recent studies of H441 human airway epithelial cells are interesting in this context. While these cells absorb $\mathrm{Na}^{+}$via an ENaC-dependent mechanism, this absorptive phenotype is seen only in glucocorticoid stimulated cells (Clunes et al., 2004; Ramminger et al., 2004) and we have therefore used this cell type as a model system to explore the factors that allow steroid hormones to regulate $G_{\text {Na. }}$. It is abundantly clear that glucocorticoids do activate SGK1 in $\mathrm{H} 441$ cells and the fact that the physiological effects of glucocorticoid-stimulation are reproduced by transient expression of a constitutively active form of SGK1 suggest strongly that this kinase is involved in this response (Thomas et al., 2004; Brown et al., 2008; Inglis et al., 2009). However, our data also show that SGK1 is active in hormone-deprived cells, despite the fact that $G_{\mathrm{Na}}$ is negligible and it is far from clear why this basal activity of SGK1 is not transduced into a $\mathrm{Na}^{+}$-absorbing phenotype (Inglis et al., 2009). Moreover, transient expression of a dominant negative SGK1 mutant suppresses the glucocorticoid-induced activation of the endogenous kinase without blocking the associated rise in $G_{\mathrm{Na}}$ and these findings (Inglis et al., 2009), in common with the present data, suggest that signalling via PI3K/SGK1 is not critical to the control of ENaC function.

It is therefore interesting that steroid hormones induce the expression of a number of other proteins 
that seem to be involved in the hormonal control of $G_{\text {Na. }}$. For example, aldosterone evokes expression of the protein encoded by n-myc downstream regulated gene 2 (NDRG2) and this protein has been shown to increase the activity of $\mathrm{ENaC}$ expressed in Xenopus oocytes and Fisher rat thyroid cells (Wielpütz et al., 2007). Steroid hormones also induce expression of glucocorticoid-inducible leucine zipper proteins 1-3 (GILZ1-3) and a growing body of evidence implicates these proteins in the control of $\mathrm{ENaC}$ function (Soundararajan et al., 2005; 2007). Interestingly, recent work has suggested that GILZ1-3 might act in cooperation with SGK1 (Soundararajan et al., 2009) and established that transient expression of GILZ1 mimics the electrophysiological effects of glucocorticoid stimulation in H441 cells (Watt et al., 2009). It is therefore possible that these mechanisms might contribute to the maintenance of basal $\mathrm{Na}^{+}$transport in hormonedeprived mpkCCD cells.

\section{Insulin-induced $\mathrm{Na}^{+}$transport}

Insulin acutely stimulated $\mathrm{Na}^{+}$absorption (see also Wilson et al., 2010) and induced phosphorylation of PKB-Ser ${ }^{473}$, NDRG1-Thr ${ }^{346 / 356 / 366}$ and PRAS40$\mathrm{Ser}^{246}$, indicating that this hormone activates PI3K and also increases the activity of the downstream protein kinases SGK1 (see also Wilson et al., 2010) and PKB. While we have assumed that these responses to insulin are mediated via true insulin receptors, we cannot exclude the possibility that these effects may be mediated, at least in part, via receptors for insulin-like growth factor 1 (IGF-1), as the concentration of insulin used here $(20 \mathrm{nM})$ may allow activation of these receptors (GonzalezRodriguez et al., 2007). However, IGF-1 and insulin are thought to control $\mathrm{Na}^{+}$transport via very similar mechanisms (Gonzalez-Rodriguez et al., 2007) and, while wortmannin, PI103 and GDC0941 had differing effects upon basal $I_{\mathrm{Eq}}$ (see above), these compounds all caused essentially complete inhibition of insulin-induced $\mathrm{Na}^{+}$absorption and abolished the insulin-induced phosphorylation of endogenous proteins. While signalling via PI3K/SGK1 does not seem to be important in the maintenance of basal $\mathrm{Na}^{+}$absorption (see above), our data suggest strongly that this signalling pathway is critical to insulin-induced $\mathrm{Na}^{+}$transport. This finding accords well with a number of earlier studies which indicate that insulin stimulates the trafficking of $\mathrm{ENaC}$ subunits to the apical membrane via a PI3K-dependent mechanism (see for example Blazer-Yost et al., 1998; 2003; Record et al., 1998; Wang et al., 2001; Arteaga and Canessa, 2006). Indeed, IGF-1 has recently been shown (Gonzalez-Rodriguez et al., 2007) to cause a
PI3K-dependent increase in the phosphorylation/ expression of SGK1 in mouse cortical collecting duct cells. However, this finding is based upon data obtained by probing Western blots with an antibody against total SGK1 and, under these conditions, changes to the phosphorylation status of this protein are inferred by the appearance of multiple, less mobile bands. While it is highly likely that this apparent phosphorylation SGK1 does lead to an increase in catalytic activity (Kobayashi and Cohen, 1999; Park et al., 1999), it is important to stress that such measurements do not provide any information relating to the catalytic activity of SGK1. In contrast, the present study assessed the activity of SGK1 by monitoring the phosphorylation of an endogenous, SGK1 substrate (NDRG1$\mathrm{Thr}^{346 / 356 / 366}$ ) and this relatively new approach (Murray et al., 2005a; Inglis et al., 2009) allows us to show unequivocally that insulin-induced $\mathrm{Na}^{+}$ transport is associated with PI3K-dependent activation of SGK1.

\section{Effects of rapamycin}

As well as inhibiting PI3K, wortmannin and PI103 also block signalling via TORC1 (Brunn et al., 1993; Raynaud et al., 2007), a kinase activated by insulin that plays an important role in the control of cellular metabolism (Proud, 2007). Because it has been suggested that TORC1 might contribute to the control of SGK1 activity by phosphorylating SGK1$\mathrm{Ser}^{422}$ (Hong et al., 2008), we also explored the effects of rapamycin, an extremely selective TORC1 inhibitor (Bain et al., 2007). Our data show clearly that rapamycin did not alter the currents generated by hormone-deprived cells; did not modify the electrometric response to insulin, and had no effect upon cellular PI3K, SGK1 and PKB activity in hormone-deprived and insulin-stimulated cells. However, a separate series of experiments confirmed that insulin did evoke P70-S6K-Thr ${ }^{389}$ phosphorylation, indicating that this hormone does activate TORC1 (Proud, 2007). Moreover, rapamycin caused complete dephosphorylation of P70-S6K-Thr ${ }^{389}$ in hormone-deprived and insulin-stimulated cells, indicating that this substance fully inactivates TORC1. Our data, in contrast with those presented by Hong et al. (2008), therefore provide no evidence to support the idea that TORC1 is involved in the control of SGK1 activity and it is therefore interesting that recently published data suggest that the apparent rapamycin-sensitive phosphorylation of SGK1-Ser ${ }^{422}$ reported by Hong et al. (2008) was actually an artefact caused by the inappropriate use of poorly selective antibodies (García-Martínez and Alessi, 2008). 
Physiological basis of insulin-induced

\section{$\mathrm{Na}^{+}$absorption}

While most evidence suggests that insulin-induced $\mathrm{Na}^{+}$transport reflects PI3K/SGK1-mediated inhibition of Nedd-4/2 (Record et al., 1998; Debonneville et al., 2001; Wang et al., 2001; Snyder et al., 2002; Alvarez De La Rosa and Canessa, 2003), insulin also induces PI3K-dependent activation of PKB (Bayascas and Alessi, 2005; Cohen, 2006). Indeed, it is the activation of PKB that allows insulin to promote glucose uptake by inducing the translocation of the type 4 glucose transporter to the plasma membrane (Cong et al., 1997). It is therefore interesting that studies of Fisher rat thyroid cells heterologously expressing $\alpha-, \beta$ - and $\gamma$-ENaC have suggested that PKB might contribute to the control of $G_{\mathrm{Na}}$ by catalyzing the phosphorylation of Nedd-4/2 (Lee et al., 2007). However, despite this seemingly clear result, studies of A6 cells heterologously expressing wildtype and mutant forms of SGK1 (Alvarez De La Rosa and Canessa, 2003) and PKB (Arteaga and Canessa, 2006) indicate that PKB is not involved in the hormonal control of $\mathrm{Na}^{+}$absorption. In an attempt to resolve this apparent contradiction, we also explored the effects of GSK650394A and Akti-1/2, as these compounds have, respectively, been reported to inhibit SGK1 (Sherk et al., 2008) and PKB (Barnett et al., 2005; Lindsley et al., 2005) selectively.

GSK650394A had a relatively modest effect ( $30 \%$ inhibition) on $\mathrm{Na}^{+}$transport in hormonedeprived cells and caused concentration-dependent inhibition of the electrometric response to insulin with essentially complete block at $10 \mu \mathrm{M}$. Analyses of extracted proteins showed that GSK650394A caused dephosphorylation of NDRG1-Thr ${ }^{346 / 356 / 366}$ in both hormone-deprived and insulin-stimulated cells and this effect was also essentially complete at $10 \mu \mathrm{M}$. The highest concentrations of GSK650394A tested did seem to cause some inhibition of insulininduced PKB-Ser ${ }^{473}$ phosphorylation, which raised the possibility that GSK650394A may also cause some inhibition of PI3K. However, GSK650394A had no effect on the phosphorylation of PRAS40$\operatorname{Ser}^{246}$, even at $10 \mu \mathrm{M}$, and it is therefore clear that this substance does not block the insulin-induced phosphorylation of PKB substrates. While this may appear surprising in view of the inhibition of PKB$\mathrm{Ser}^{473}$ phosphorylation (see above), Logie et al. (2007) have shown that there is considerable extra capacity in the PKB-dependent signalling pathway. Indeed, their studies of liver cells indicated that endogenous PKB activity must be reduced to $<10 \%$ of the basal level before the phosphorylation of downstream targets is compromised (Logie et al., 2007). The present data therefore confirm (Sherk et al., 2008) that GSK650394A suppresses signalling via SGK1 and not via PKB. The finding that this compound fully suppressed the electrometric response to insulin therefore supports the view that this response is mediated via PI3K/SGK1 (Alvarez De La Rosa and Canessa, 2003; Arteaga and Canessa, 2006) rather than via PI3K/PKB (Lee et al., 2007).

Akti-1/2 also caused concentration-dependent inhibition of the electrometric response to insulin and this effect, in common with the effect of GSK650394A, was essentially complete at $10 \mu \mathrm{M}$. Akti-1/2 also caused essentially complete dephosphorylation of PKB-Ser ${ }^{473}$ and PRAS40-Ser ${ }^{246}$ in both hormone-deprived and insulin-stimulated cells, which confirms that this compound is an effective inhibitor of PKB (Barnett et al., 2005; Lindsley et al., 2005). However, our data suggest that $10 \mu \mathrm{M}$ Akti$1 / 2$ is needed for complete inhibition of PKB and this contrasts with data from liver cells, which reported full inhibition at concentrations below $1 \mu \mathrm{M}$ (Logie et al., 2007). Our findings do, however, accord with earlier work, which suggests that concentrations as high as $20 \mu \mathrm{M}$ are needed to inhibit PKB fully (Barnett et al., 2005). The present data show that Akti-1/2 also causes dephosphorylation of NDRG1-Thr ${ }^{346 / 356 / 366}$ and this effect, in common with the dephosphorylation of PRAS40-Ser ${ }^{246}$, was complete at $10 \mu \mathrm{M}$. As the phosphorylation of NDRG1$\mathrm{Thr}^{346 / 356 / 366}$ is strictly dependent upon SGK1 (Murray et al., 2005a,b), this result shows that Akti1/2 inhibits both PKB and SGK1 under the present conditions and it is therefore interesting that $10 \mu \mathrm{M}$ Akti-1/2 has been shown to cause substantial ( 75\%) inhibition of SGK1 in vitro (Logie et al., 2007). Hence, our data indicate that Akti-1/2 is not a selective PKB blocker, and this result highlights the difficulties inherent to all experiments based around such small molecule inhibitors of protein kinases (Bain et al., 2007). All data obtained using Akti-1/2 must therefore be treated with caution and, at present, it is impossible for us to exclude the possibility that PKB may contribute to the control of $\mathrm{Na}^{+}$ transport by acting in concert with SGK1 (Lee et al., 2007).

\section{Significance of the present findings}

The present data suggest that signalling via PI3K/ SGK1 is not important to the maintenance of basal $\mathrm{Na}^{+}$transport, because hormone-deprived cells continued to absorb $\mathrm{Na}^{+}$when PI3K had been fully inactivated using PI103 or GDC-0941. It is therefore understandable that deletion of the $s g k 1$ gene has no overt effect upon renal $\mathrm{Na}^{+}$handling in animals fed a normal diet (Wulff et al., 2002) and this finding, in common with the present data, suggests strongly that SGK1 is not involved in basal $\mathrm{Na}^{+}$ transport. However, signalling via PI3K does seem to 
be critical for insulin-stimulated $\mathrm{Na}^{+}$transport and the finding that GSK650394A abolished the insulininduced $\mathrm{Na}^{+}$transport suggests strongly that this response is mediated via SGK1 (see also Record et al., 1998; Wang et al., 2001; Arteaga et al., 2006). Interestingly, sgk1 gene deletion does block the insulininduced reduction in urinary $\mathrm{Na}^{+}$excretion (Huang et al., 2006) and it is therefore possible that drugs such as GSK650394A, which selectively inactivate SGK1, might become useful in the treatment of fluid retention/oedema that can complicate the management of type 2 diabetes.

\section{Acknowledgements}

This work was supported by an MRC Project grant (SMW) and by a studentship from the MRC doctoral training scheme. The authors are grateful to Professors Dario Alessi and Phillip Cohen for the provision of many reagents and for valuable advice concerning their use.

\section{Conflict of interest}

The authors report no conflict of interest.

\section{References}

Alvarez De La Rosa D, Canessa CM (2003). Role of SGK in hormonal regulation of epithelial sodium channel in A6 cells. Am J Physiol Cell Physiol 284: C404-C414.

Arteaga MF, Canessa C (2006). Functional specificity of Sgk1 and Akt1 on ENaC activity. Am J Physiol Renal Physiol 289: 90-96.

Arteaga MF, Wang L, Ravid T, Hochstrasser M, Canessa CM (2006). An amphipathic helix targets serum and glucocorticoid-induced kinase 1 to the endoplasmic reticulum-associated ubiquitin-conjugation machinery. Proc Natl Acad Sci USA 103: 11178-11183.

Atchley D, Loeb RF, Richards DW, Benedict EM, Driscoll ME (1936). On diabetic acicosis. A detailed study of electrolyte balances following the withdrawal and reestablishment of insulin therapy. J Clin Invest 12: 297-326.

Bachhuber T, Almaca J, Aldehni F, Mehta A, Amaral MD, Schreiber R et al. (2008). Regulation of the epithelial $\mathrm{Na}+$ channel by the protein kinase CK2. J Biol Chem 283: 13225-13232.

Bain J, Plater L, Elliott M, Shpiro N, Hastie J, McClauchlan H et al. (2007). The selectivity of protein kinase inhibitors: a further update. Biochem J 408: 297-315.
Barnett SF, Defeo-Jones D, Fu S, Hancock PJ, Haskell KM, Jones RE et al. (2005). Identification and characterization of pleckstrin-homology-domain-dependent and isoenzyme-specific Akt inhibitors. Biochem J 385: 399-408.

Bayascas JR, Alessi DR (2005). Regulation of Akt/PKB Ser473 phosphorylation. Mol Cell 18: 143-145.

Bens M, Vallet V, Cluzeaud F, Padcula-Letallec L, Kahn A, Rafestin-Oblin ME et al. (1999).

Corticosteroid-dependent sodium transport in a novel immortalized mouse collecting duct principal cell line. J Am Soc Nephrol 10: 923-934.

Blazer-Yost BL, Liu XH, Helman SI (1998). Hormonal regulation of ENaCs: insulin and aldosterone. Am J Physiol Cell Physiol 274: 1373-1379.

Blazer-Yost BL, Esterman MA, Vlahos CJ (2003). Insulin-stimulated trafficking of $\mathrm{ENaC}$ in renal cells requires PI3-kinase activity. Am J Physiol Cell Physiol 284: C1645-C1653.

Brown SG, Gallacher M, Olver RE, Wilson SM (2008). The regulation of selective and non-selective $\mathrm{Na}^{+}$ conductances in H441 human airway epithelial cells. Am J Physiol Lung Cell Mol Physiol 294: L942-L954.

Brunn GJ, Williams J, Sabers C, Wiederrecht G, Lawrence JC, Abraham RT (1993). Direct inhibition of the signaling functions of the mammalian target of rapamycin by the phosphoinositide 3-kinase inhibitors, wortmannin and LY294002. EMBO J 15: 5256-5267.

Buckingham RE, Hanna A (2007). Thiazolidinedione insulin sensitizers and the heart: a tale of two organs. Diabetes Obes Metab 10: 312-328.

Canessa CM, Horisberger JD, Rossier BC (1993). Epithelial sodium channel related to proteins involved in neurodegeneration. Nature 361: 467-470.

Canessa CM, Schild L, Buell G, Thorens B, Gautschi I, Horisberger JD et al. (1994). Amiloride-sensitive epithelial $\mathrm{Na}^{+}$channel is made of three homologous subunits. Nature 367: 463-466.

Clunes MT, Butt AG, Wilson SM (2004). A glucocorticoid-induced $\mathrm{Na}^{+}$conductance in human airway epithelial cells identified by perforated patch recording. J Physiol Lond 557: 809-819.

Cohen P (2006). Timeline - the twentieth century struggle to decipher insulin signalling. Nat Rev Mol Cell Biol 7: 867-873.

Cong LN, Chen H, Li YH, Zhou LX, McGibbon MA, Taylor SI et al. (1997). Physiological role of Akt in insulin-stimulated translocation of GLUT4 in transfected rat adipose cells. Mol Endocrinol 11: 1881-1890.

Davies SP, Reddy H, Caivano M, Cohen P (2000). Specificity and mechanism of action of of some commonly used protein kinase inhibitors. Biochem J 351: 95-105.

Debonneville C, Flores SY, Kamynina E, Plant PJ, Tauxe C, Thomas MA et al. (2001). Phosphorylation of Nedd4-2 by Sgk1 regulates epithelial channel surface expression. EMBO J 20: 7052-7059. 
Defronzo RA, Cooke CR, Andres R, Faloona GR, Davis PJ (1975). Effect of insulin on renal handling of sodium, potassium, calcium, and phosphate in man. J Clin Invest 55: 845-855.

Defronzo RA, Goldberg M, Agus ZS (1976). Effects of glucose and insulin on renal electrolyte transport. J Clin Invest 58: 83-90.

Folkes AJ, Ahmadi K, Alderton WK, Alix S, Baker SJ, Box G et al. (2008). The identification of 2-(1H-indazol4-yl)-6-(4-methanesulfonyl-piperazin-1-ylmethyl)-4morphol in-4-yl-thieno 3,2-d pyrimidine (GDC-0941) as a potent, selective, orally bioavailable inhibitor of class I PI3 kinase for the treatment of cancer. J Med Chem 51: 5522-5532.

García-Martínez JM, Alessi DR (2008). mTOR complex 2 (mTORC2) controls hydrophobic motif phosphorylation and activation of serum- and glucocorticoid-inducible protein kinase 1 (SGK1). Biochem J 416: 375-385.

Gonzalez-Rodriguez E, Gaeggeler HP, Rossier BC (2007). IGF-1 vs insulin: respective roles in modulating sodium transport via the PI-3 kinase/Sgk1 pathway in a cortical collecting duct cell line. Kidney Int 71: 116-125.

Guan Y, Hao C, Cha DR, Rao R, Lu W, Kohan DE et al. (2005). Thiazolidinediones expand body fluid volume through PPAR $\gamma$ stimulation of ENaC-mediated renal salt absorption. Nat Med 11: 861-866.

Hong F, Larrea MD, Doughty C, Kwiatkowski DJ, Squillance R, Slingerland J (2008). mTOR-Raptor binds and activates SGK1 to regulate p27 phosphorylation. Mol Cell 30: 701-711.

Hong GH, Lockhart A, Davis B, Rahmoune H, Baker S, Ye L et al. (2003). PPAR $\gamma$ activation enhances cell surface ENaCa via upregulation of SGK1 in human collecting duct cells. FASEB J 17: 1966+.

Huang DY, Boini KM, Freidrich B, Metzger M, Just L, Osswald $\mathrm{H}$ et al. (2006). Blunted hypertensive effect of combined fructose and high salt intake in gene targeted mice lacking serum and gluccocorticoid-inducible kinase SGK1. Am J Physiol Regul Integr Comp Physiol 290: R935-R944.

Inglis SK, Gallacher M, Brown SG, McTavish N, Getty J, Husband EM et al. (2009). SGK1 activity in $\mathrm{Na}^{+}$ absorbing human airway epithelial cells monitored by assaying NDRG1-Thr ${ }^{346 / 356 / 366}$ phosphorylation. Pflügers Arch 457: 1287-1301.

Kanelis V, Rotin D, Forman-Kay JD (2001). Solution structure of a Nedd 4 WW domain-ENaC peptide complex. Nat Struct Biol 8: 407-412.

Kobayashi T, Cohen P (1999). Activation of serum- and glucocorticoid-regulated protein kinases by agonists that activate phosphatidylinositol 3-kinase is mediated by 3-phosphoinositide-dependent protein kinase 1 (PDK1) and PDK2. Biochem J 339: 319-328.

Kovacina KS, Park GY, Bae SS, Guzzetta AW, Schaefer E, Birnbaum MJ et al. (2003). Identification of a proline-rich Akt substrate as a 14-3-3 binding partner. J Biol Chem 278: 10189-10194.
Lee I-H, Dinudom A, Sanchez-Perez A, Kumar S, Cook DI (2007). Akt mediates the effects of insulin on epithelial sodium channels by inhibiting Nedd-4-2. J Biol Chem 282: 29866-29873.

Lindsley CW, Zhao Z, Leister WH, Robinson RG, Barnett SF, Defeo-Jones D et al. (2005). Allosteric Akt (PKB) inhibitors: discovery and SAR of isozyme selective inhibitors. Bioorg Med Chem Lett 15: 761-764.

Loffing J, Korbmacher C (2009). Regulated sodium transport in the renal collecting tubule (CNT) via the epithelial sodium channel (ENaC). Pflügers Arch 458: 111-135.

Logie L, Ruiz-Alcaraz AJ, Keane M, Woods YL, Bain J, Marquez R et al. (2007). Characteristics of a protein kinase $\mathrm{B}$ inhibitor in vitro and in insulin-treated liver cells. Diabetes 56: 2218-2227.

Murray JT, Cambell DG, Morrice N, Auld G, Shpiro N, Marquez R et al. (2005a). Exploitation of KESTREL to identify NDRG family members as physiological substrates of SGK1 and GSK3. Biochem J 385: 1-12.

Murray JT, Cummings LA, Bloomberg GB, Cohen P (2005b). Identification of different specificity requirements between SGK1 and PKB $\alpha$. FEBS Lett 579: 991-994.

Park J, Leong MLL, Buse P, Maiyar AC, Firestone GL, Hemmings BA (1999). Serum and

glucocorticoid-inducible kinase (SGK) is a target of the PI 3-kinase-stimulated signaling pathway. EMBO J 18: 3024-3033.

Paunescu TG, Blazer-Yost BL, Vlahos CJ, Helman SI (2000). LY-294002-inhibitable PI 3-kinase and regulation of baseline rates of $\mathrm{Na}^{+}$transport in A6 epithelia. Am J Physiol Cell Physiol 279: C236-C247.

Proud CG (2007). Signalling to translation: how signal transduction pathways control the protein synthetic machinery. Biochem J 403: 217-234.

Ramminger SJ, Richard K, Inglis SK, Land SC, Olver RE, Wilson SM (2004). A regulated apical $\mathrm{Na}^{+}$conductance in dexamethasone-treated H441 airway epithelial cells. Am J Physiol Lung Cell Mol Physiol 287: L411-L419.

Raynaud FI, Eccles S, Clarke PA, Hayes A, Nutley B, Alix S et al. (2007). Pharmacologic characterization of a potent inhibitor of class I phosphatidylinositide 3-kinases. Cancer Res 67: 5840-5850.

Record RD, Froelich LL, Vlahos CJ, Blazer-Yost BL (1998). Phoshatidylinositol 3-kinase activation is required for insulin-stimulated sodium transport in A6 cells. Am J Physiol Endocrinol Metab 274: E611-E617.

Schild L, Lu Y, Gautschi I, Schneeberger E, Lifton RP, Rossier BC (1996). Identification of a PY motif in the epithelial Na channel subunits as a target sequence for mutations causing channel activation found in Liddle syndrome. EMBO J 15: 2381-2387.

Sherk AB, Frigo DE, Schnackenberg CG, Bray JD, Laping NJ, Trizna W et al. (2008). Development of a small-molecule serum- and glucocorticoid-regulated 
kinase-1 antagonist and its evaluation as a prostate cancer therapeutic. Cancer Res 68: 7475-7483.

Shi HK, Asher C, Yung YV, Kligman L, Reuveny E, Seger R et al. (2002). Casein kinase 2 specifically binds to and phosphorylates the carboxy termini of $\mathrm{ENaC}$ subunits. Eur J Biochem 269: 4551-4558.

Snyder PM, Olsen DR, Thomas BC (2002). Serum and glucocorticoid-regulated kinase modulates Nedd4-2-mediated inhibition of the epithelial $\mathrm{Na}^{+}$ channel. J Biol Chem 277: 5-8.

Snyder PM, Steines JC, Olson DR (2004). Relative contribution of Nedd4 and Nedd4-2 to ENaC regulation in epithelia determined by RNA interference. J Biol Chem 279: 5042-5046.

Soundararajan R, Zhang TT, Wang J, Vandewalle A, Pearce D (2005). A novel role for glucocorticoid-induced leucine zipper protein in epithelial sodium channel-mediated sodium transport. J Biol Chem 280: 39970-39981.

Soundararajan R, Wang J, Melters D, Pearce D (2007). Differential activities of glucocorticoid-induced leucine zipper protein isoforms. J Biol Chem 282: 36303-36313.

Soundararajan R, Melters D, Shih I-C, Wang J, Pearce D (2009). Epithelial sodium channel regulated by differential composition of a signaling complex. Proc Natl Acad Sci USA 106: 7804-7809.

Thomas CP, Campbell JR, Wright PJ, Husted RF (2004). cAMP-stimulated $\mathrm{Na}^{+}$transport in $\mathrm{H} 441$ distal lung epithelial cells: role of PKA, phosphatidylinositol 3-kinase, and sgk1. Am J Physiol Lung Cell Mol Physiol 287: L843-L851.
Tiwari S, Riazi S, Ecelbarger CA (2007). Insulin's impact on renal sodium transport and blood pressure in health, obesity and diabetes. Am J Physiol Renal Physiol 293: F974-F984.

Tokuda S, Niisato N, Morisaki S, Marunaka Y (2002). Calmodulin-dependent regulation of hypotonicity-induced translocation of $\mathrm{ENaC}$ in renal epithelial A6 cells. Biochem Biophys Res Commun 298: 619-623.

Wang J, Barbary P, Maiyar A, Rozansky DJ, Bhargava A, Leong M et al. (2001). SGK integrates insulin and mineralocorticoid regulation of epithelial sodium transport. Am J Physiol Renal Physiol 280: F303-F313.

Watt G, Gallacher M, Land SC, McTavish N, Wilson SM (2009). Glucocorticoid-inducible leucine zipper protein 1 (GILZ1) induces membrane $\mathrm{Na}^{+}$current $\left(\mathrm{I}_{\mathrm{Na}}\right)$ in hormone-deprived airway epithelial cells. Proc Physiol Soc 16: C6.

Wielpütz MO, Lee I-H, Dinudom A, Boulkroun S, Farman N, Cook DI et al. (2007). NDRG2 stimulates amiloride-sensitive $\mathrm{Na}+$ currents in Xenopus oocytes and Fisher rat thyroid cells. J Biol Chem 282: 28262-28273.

Wilson SM, Mansley MK, Getty J, Husband EM, Inglis SK, Hansen MK (2010). Effects of peroxisome proliferator-activated receptor $\gamma$ agonists on $\mathrm{Na}^{+}$ transport and activity of the kinase SGK1 in epithelial cells from lung and kidney. Br J Pharmacol 159: 678-688.

Wulff P, Vallon V, Huang DY, Volkl H, Yu F, Richter K et al. (2002). Impaired renal $\mathrm{Na}^{+}$retention in the sgk1-knockout mouse. J Clin Invest 110: 1263-1268. 